\title{
Targeting androgen-independent pathways: new chances for patients with prostate cancer?
}

\author{
C. Cattrini ${ }^{\mathrm{a}, \mathrm{b}, *}$, E. Zanardi ${ }^{\mathrm{a}, \mathrm{b}}$, G. Vallome ${ }^{\mathrm{a}, \mathrm{b}}$, A. Cavo ${ }^{\mathrm{a}, \mathrm{b}}$, L. Cerbone ${ }^{\mathrm{a}, \mathrm{b}}$, A. Di Meglio ${ }^{\mathrm{a}, \mathrm{b}}$,

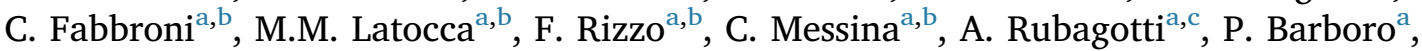 \\ F. Boccardo ${ }^{\mathrm{a}, \mathrm{b}}$ \\ a Academic Unit of Medical Oncology, San Martino University Hospital - IST National Cancer Research Institute, L.go R. Benzi 10, 16132, Genoa, Italy \\ b Department of Internal Medicine and Medical Specialties (DIMI), School of Medicine, University of Genoa, V.le Benedetto XV 6, 16132, Genoa, Italy \\ ${ }^{c}$ Department of Health Sciences (DISSAL), University of Genoa, Via A. Pastore 1, 16132, Genoa, Italy
}

\section{A R T I C L E I N F O}

\section{Keywords:}

Androgen receptor

Castration-resistant prostate cancer

Stress response

Survival pathways

Tumor heterogeneity

Phenotypic plasticity

\begin{abstract}
A B S T R A C T
Androgen deprivation therapy (ADT) is the mainstay treatment for advanced prostate cancer (PC). Most patients eventually progress to a condition known as castration-resistant prostate cancer (CRPC), characterized by lack of response to ADT. Although new androgen receptor signaling (ARS) inhibitors and chemotherapeutic agents have been introduced to overcome resistance to ADT, many patients progress because of primary or acquired resistance to these agents. This comprehensive review aims at exploring the mechanisms of resistance and progression of PC, with specific focus on alterations which lead to the activation of androgen receptor (AR)-independent pathways of survival. Our work integrates available clinical and preclinical data on agents which target these pathways, assessing their potential clinical implication in specific settings of patients. Given the rising interest of the scientific community in cancer immunotherapy strategies, further attention is dedicated to the role of immune evasion in PC.
\end{abstract}

\section{Introduction}

Prostate cancer (PC) accounts for 1 in 5 new diagnoses of cancer in the United States of America and, despite the recent improvements, this neoplasm still causes more than 26,000 deaths per year (Siegel et al., 2016). The prostate gland is constituted both of basal and luminal epithelium arranged in a fibro-muscular stromal network (Packer and Maitland, 2016). Based on the observation that human PC are mostly luminal-like adenocarcinomas, the luminal origin of PC is supported by several studies (Wang et al., 2009; Wang et al., 2014). However, the basal cell transformation into tumorigenic luminal cells is also suggested as an alternative origin of PC (Packer and Maitland, 2016). Differently from basal cells, the luminal secretory cells of normal prostate require androgens for survival and undergo apoptosis upon androgen withdrawal (Long et al., 2005). Therefore, the androgen receptor (AR) has been historically considered the most relevant target to control the growth and dissemination of PC and this notion has guided the treatment of PC for several years (Watson et al., 2015). The time has probably come for this paradigm to be changed. First, not all hormonenaïve PC appear to be equally responsive to androgen deprivation therapy (ADT). Recently, Feng et al. segregated more than 3500 PC samples into luminal A, luminal B, and basal subtypes using the PAM50 classifier, which distinguishes basal and luminal breast cancers, and showed that only luminal B PC are significantly associated with postoperative response to ADT (Feng et al., 2017). Second, the high frequency of AR aberrations, found in highly pretreated patients with PC, suggests that AR probably acts as the main driver of proliferation and progression in some of these patients too, but this observation does not tell the whole story (Robinson et al., 2015). In fact, the poorly differentiated and aggressive PC cells show low levels of AR and prostate specific antigen (PSA) expression and sustain proliferation and invasion in a completely hormone-independent manner (Ellis and Loda, 2015; Miyamoto et al., 2015). Stemness signatures, self-renew capacity, resistance to immune-response, phenotypic plasticity and lack of contact inhibition are the main characteristics of these clones, which are refractory to therapies, exhibit high clonogenic potential, and show longterm tumor-propagating capacity (Boyd et al., 2012; Ellis and Loda, 2015; Mahal et al., 2016; Qin et al., 2012; Roubaud et al., 2016). These cells may be the result of multiple genetic and phenotypic alterations induced by treatments, but may also represent pre-existing

\footnotetext{
* Corresponding author at: Academic Unit of Medical Oncology, San Martino University Hospital - IST National Cancer Research Institute, L.go R. Benzi 10, 16132, Genoa, Italy. Tel.: + 39010555 8930/8861; fax: + 390105556385 .
}

E-mail address: carlo.cattrini@gmail.com (C. Cattrini). 


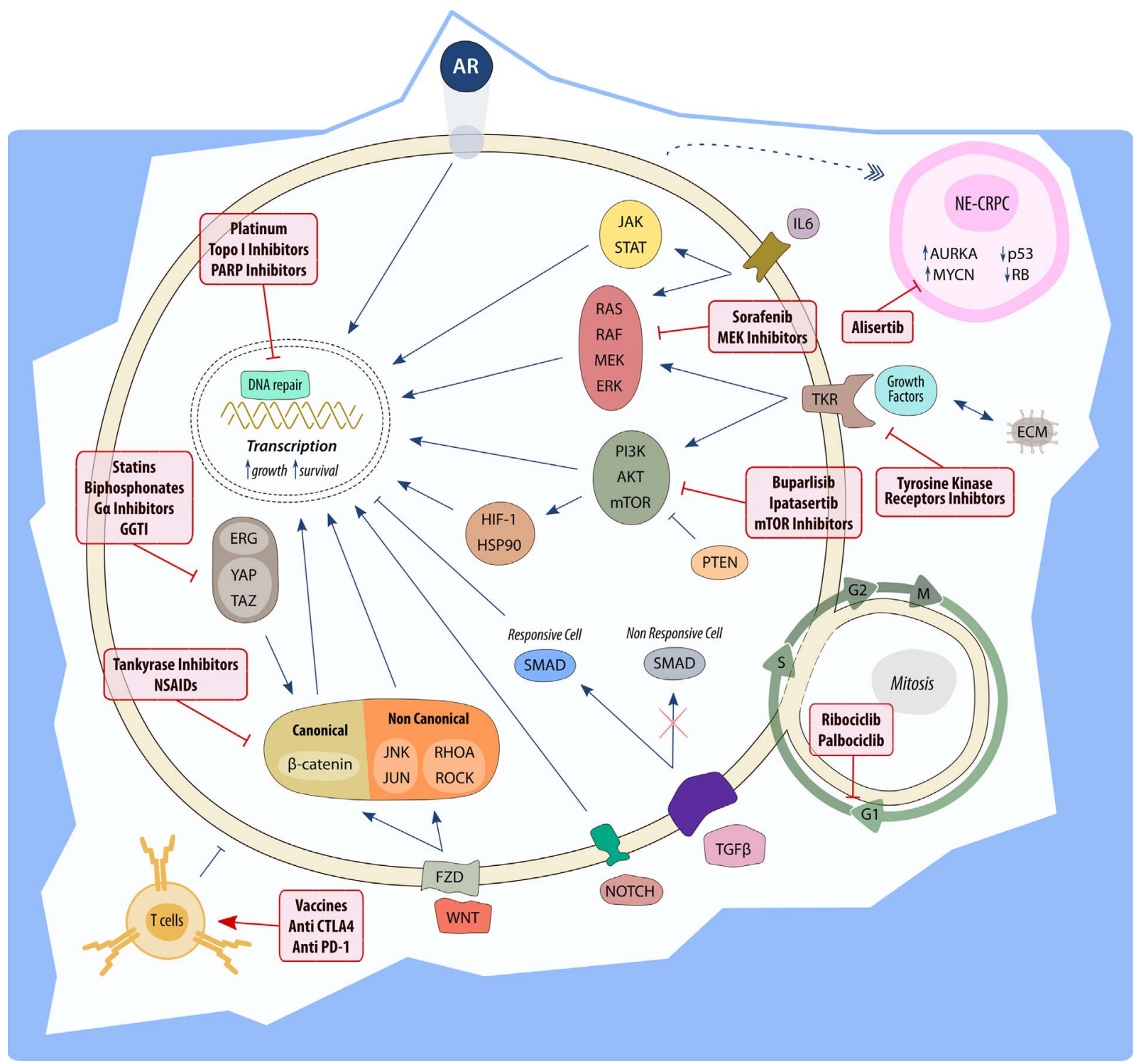

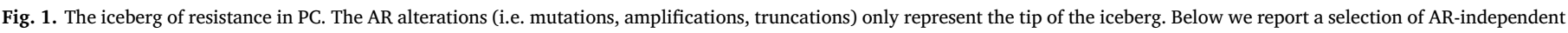

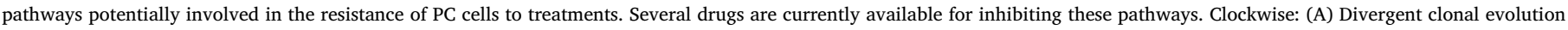

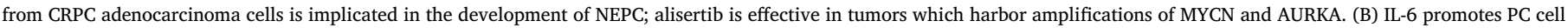

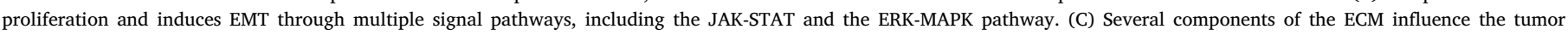

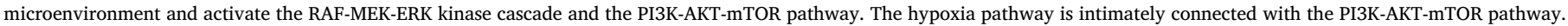

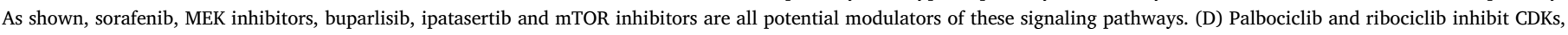

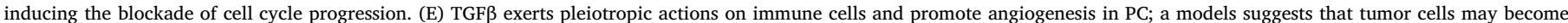

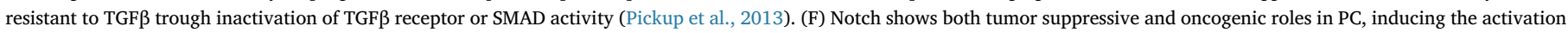

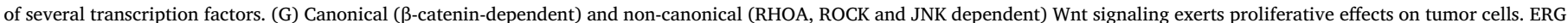

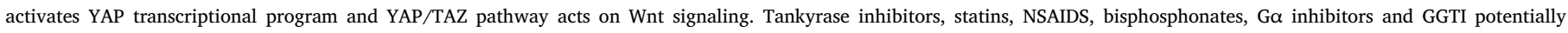

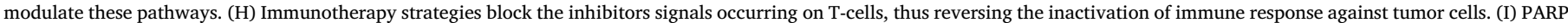

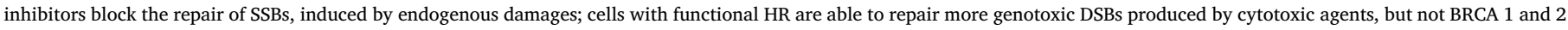

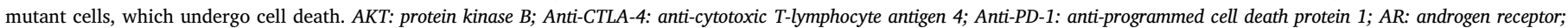

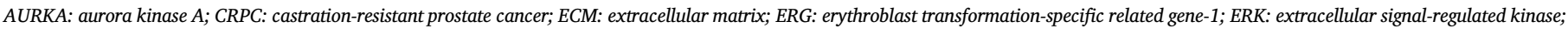

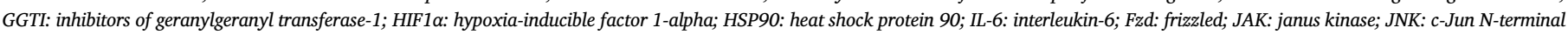

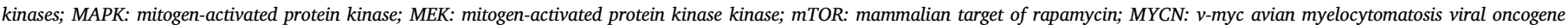

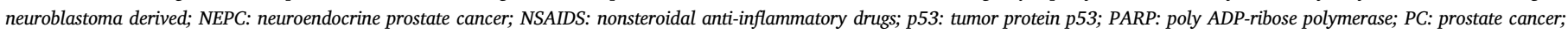

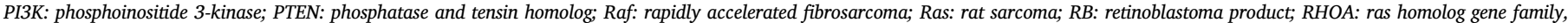

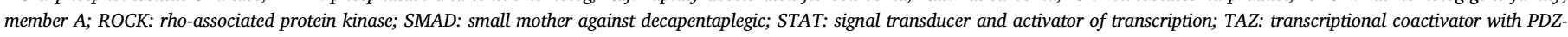

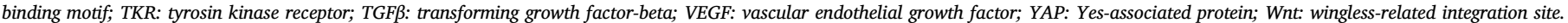

subpopulations, which are selected based on their ability to survive in adverse conditions. Genomic rearrangements, rare mutations and epigenetic phenomena amplify transcriptomic diversity of PC, converging on specific cellular functions and AR-independent signaling pathways of survival and proliferation (Wyatt et al., 2013) (Fig. 1). Therefore, primary or acquired resistance to treatments is probably the result of the extensive genetic diversity and heterogeneity of PC rather than of a linear evolutionary process (Boyd et al., 2012; Liu et al., 2015). In addition to genetic or epigenetic events that occur in tumor cells, a favorable local microenvironment is an invariable prerequisite for the growth and the dissemination of this neoplasm (Barron and Rowley, 2012). Chemo-hormonal and mechanical signals modulate the behavior 
Table 1

Promising agents targeting AR-independent pathways in patients with PC.

\begin{tabular}{|c|c|c|}
\hline TARGET & DRUG & REFERENCES \\
\hline AKT & Ipatasertib, AZD5363 & $\begin{array}{l}\text { (Crabb et al., 2017; De Bono, J. S. et al., } \\
\text { 2016; Kolinsky et al., 2017) }\end{array}$ \\
\hline AURKA & Alisertib & (Beltran et al., 2016a) \\
\hline Hh & Itraconazole & (Antonarakis et al., 2013) \\
\hline Hsp27 & Apatorsen & (Chi et al., 2017) \\
\hline mTOR & Everolimus & $\begin{array}{l}\text { (Chow et al., 2016; Gross et al., 2015; } \\
\text { Templeton et al., 2013) }\end{array}$ \\
\hline PARP-1 & Olaparib, veliparib & (Hussain et al., 2016; Mateo et al., 2015) \\
\hline PD-1 & $\begin{array}{l}\text { Durvalumab, } \\
\text { pembrolizumab }\end{array}$ & $\begin{array}{l}\text { (Graff et al., 2016a; Hansen et al., 2016; } \\
\text { Karzai et al., 2017) }\end{array}$ \\
\hline RAF & Sorafenib & (Meyer et al., 2014) \\
\hline
\end{tabular}

of tumor, stromal and immune cells, affecting the progression of PC. Alterations in the cell structure, shape and polarity support the proliferation and migration of PC cells: several pathways activated during early stages of embryonic development also play key roles during tumorigenesis (Azzolin et al., 2012; Bissell and Hines, 2011; Taipale and Beachy, 2001; Zanconato et al., 2016b). Cell-surface molecules, growth and transcription factors are also frequently implicated in the activation of AR-independent pathways and in the process of epithelial-mesenchymal transition (EMT). Several studies have assessed drugs which target these AR-indipendent pathways of survival and have been focused on unselected, advanced, pluri-treated patients with castrationresistant prostate cancer (CRPC) (Table 1). However, specific molecular alterations, alternative to AR, are found in restricted subgroups of patients and in limited subsets of PC cells. Therefore, initial failures should not discourage further investigations on these drugs and new trials should be guided by the accurate identification of patients who might potentially benefit from these treatments. In addition, therapeutic interventions on these clones should be probably pursued as early as possible, in order to avoid the praecox selection of AR-indifferent cells, which gradually acquire more and more aggressive phenotypes.

\section{Methods}

This manuscript focuses on the results published by the Stand Up To Cancer - Prostate Cancer Foundation (SU2C-PCF) International Dream Team in 2015 (Robinson et al., 2015), which revealed the main alterations found in patients with metastatic castration-resistant prostate cancer (mCRPC). An analytical review of literature was implemented to confirm these findings and to assess the potential clinical implication of drugs that target these alterations. A systematic search of on-going, phase I, II and III clinical studies was performed in Feb 2017 on ClinicalTrial.gov, PubMed, American Society of Clinical Oncology (ASCO) and European Society of Medical Oncology (ESMO) web-sites. Given the wide range of pathways explored, in vitro and in vivo studies were considered on the basis of their relevance to the topic. The search strategy included the terms metastatic prostate cancer (mPC), CRPC, molecular biology, AR, androgen receptor signaling (ARS), phosphoinositide 3-kinase (PI3K), protein kinase B (AKT), mammalian target of rapamycin (mTOR), poly ADP-ribose polymerase (PARP), wingless-related integration site (Wnt), mitogen-activated protein kinase (MAPK), rat sarcoma (RAS), rapidly accelerated fibrosarcoma (Raf), mitogenactivated protein kinase kinase (MEK), extracellular signal-regulated kinase (ERK), breast cancer-related gene (BRCA), cyclin-dependent protein kinases (CDK), androgen-regulated transmembrane protease serine 2 (TMPRSS2)/erythroblast transformation-specific related gene1 (ERG) fusion, Yes-associated protein (YAP), transcriptional coactivator with PDZ-binding motif (TAZ), Notch, Hedgehog (Hh), neuroendrocrine prostate cancer (NEPC), aurora kinase A (AURKA), myc avian myelocytomatosis viral oncogene neuroblastoma derived (MYCN), immunotherapy, anti-cytotoxic T-lymphocyte antigen 4 (anti-CTLA-4), anti-programmed cell death protein 1 (anti-PD-1), vaccines.

\section{Kinase-dependent pathways}

More than $50 \%$ of patients with mCRPC harbor alterations in kinase-dependent signals, involving the PI3K-AKT-mTOR or the MAPKERK pathways (Robinson et al., 2015). Although many efforts have been carried out in recent years, the majority of tyrosine kinase (TK) inhibitors (i.e. cabozantinib, dasatinib, sunitinib) or growth factors inhibitors (i.e. bevacizumab), that were tested in unselected populations of patients with PC, proved ineffective (Lorente and De Bono, 2014; Messina et al., 2016). These failures may be attributed to the lack of absolute kinase dependency of CRPC and to the rare occurrence of TK genetic mutations (Grasso et al., 2012; Wyatt and Gleave, 2015). In addition, bypass signaling, epigenetic events or alterations in downstream effectors may also activate these pathways, independently of TK or growth factors inhibition (Lin and Shaw, 2016). Therefore, many attempts have been performed to inhibit the downstream checkpoints of these pathways, rather than the upstream elements.

\subsection{PI3K-AKT-mTOR pathway}

The PI3K-AKT-mTOR pathway is involved in cell survival, proliferation, differentiation and angiogenesis (Fruman and Rommel, 2014); however, its role in the anchorage-independent growth of tumor cells and oncogenic ECM remodeling is also well established (Hirsch et al., 2014). PI3K activation phosphorylates and activates AKT, which in turn activates mTOR; the phosphatase and tensin homolog (PTEN) is a tumor suppressor protein, that exerts an inhibitory effect on this signaling pathway (Luo et al., 2003). In addition, the activation of Twist induced by AKT represses the E-cadherin-mediated cell to cell adhesion, thus contributing to the EMT process (Xue et al., 2012). Preclinical data demonstrated a reciprocal regulation between PI3K and ARS during PC initiation and progression, pointing to a direct role of PTEN loss and PI3K/AKT activation in repressing AR expression and activation (Lee et al., 2015). PI3K-AKT-mTOR thus represents an interesting target to block a significant number of basic responses leading to PC cells proliferation and dissemination (Bitting and Armstrong, 2013; Hirsch et al., 2014). Buparlisib, an oral investigational pan PI3K inhibitor, either alone or when added to AR inhibition, did not improve PFS over historic control data in men with mCRPC progressing on enzalutamide (Armstrong et al., 2015). Also PX-866, a pan-isoform inhibitor of class I PI3K, showed modest activity in docetaxel-naïve CRPC patients (NCIC, 2013). Dactolisib, a novel small molecule, pan-class I PI3K and mTOR signaling inhibitor was recently tested in a phase I/II trial in combination with abiraterone acetate in chemo-naïve MCRPC; this trial was stopped during phase I, due to multiple toxicities (Siegel et al., 2014). Encouraging results were recently presented by De Bono et al. at the 2016 ESMO Annual Meeting (De Bono et al., 2016a,b). Ipatasertib, an AKT inhibitor, in combination with abiraterone was compared to abiraterone alone in a phase II study that enrolled 253 patients with mCRPC after docetaxel chemotherapy. This combination did not show statistically significant increased radiologic PFS in the unselected population of CRPC compared to abiraterone alone (median 8.2 vs 6.4 months; hazard ratio $(\mathrm{HR})=0.75 ; p=0.17$ ). However, a subgroup analysis revealed that patients with PTEN loss had superior radiologic PFS benefit when treated with ipatasertib $400 \mathrm{mg}$ compared to those without PTEN loss (rPFS: 11.5 vs 7.5 months HR:0.39 [0.22-0.70] $p=0.006$ ) (De Bono et al., 2016a,b). Also, the lowest dosage of ipatasertib $(200 \mathrm{mg})$ in combination with abiraterone determined a rPFS advantage in patients with PTEN loss compared to those without PTEN alterations (rPFS: 11.1 vs 4.6 months HR:0.46 [0.22-0.70] $p=0.028$ ). When PTEN is deleted, AKT regulates PC cells proliferation, while AR regulates their survival, thus offering a possible explanation of these results and supporting the rationale of combining AKT blockers with AR modulators (Sittadjody et al., 2016). This notion has guided a phase I 
dose-escalation study of enzalutamide in combination with the AKT inhibitor AZD5363 in heavily pretreated patients with mCRPC (Kolinsky et al., 2017). AZD5363 at the dosage of $300 \mathrm{mg}$ twice daily four days on - three days off combined with enzalutamide $160 \mathrm{mg}$ once daily was well tolerated (only one patient experienced G3 maculopapular rash) and this dosage was recommended for the following phase II trials. Among ten patients who completed 12 weeks of treatment, three met at least one of the criteria for response; in addition, one patient who had previously progressed on enzalutamide exhibited partial response, suggesting that AZD5363 may be able to overcome resistance to enzalutamide. AZD5363 was also investigated in combination with docetaxel and prednisolone in the ProCAID trial, a phase I study, which enrolled ten patients with mCRPC (Crabb et al., 2017); even though this study was not designed to evaluate the efficacy of this combination, PSA reduction from baseline level to $<50 \%$ at 12 weeks of treatment was seen in seven $(70 \%)$ of patients. Several compounds (i.e. temsirolimus, everolimus, ridaforolimus or sapanisertib) have been developed to specifically inhibit mTOR. Two phase II trials showed minimal activity of temsirolimus as a single agent both in chemo-naïve and in docetaxel-treated CRPC patients (Armstrong et al., 2013; Kruczek et al., 2013). This drug was also tested as maintenance treatment following successful docetaxel chemotherapy, and resulted in a median time to treatment failure of 24.3 weeks (Emmenegger et al., 2015). The activity of everolimus, either as monotherapy or in combination with other drugs, was tested in patients with mCRPC in several clinical trials (Roviello et al., 2016). A phase II trial assessed singleagent everolimus in 37 chemotherapy-naive patients with CRPC (Templeton et al., 2013). Though PTEN loss is correlated with an overall poor survival (Lotan et al., 2016), patients with PTEN-deficient tumors treated with this drug showed a trend towards longer PFS and increased likelihood of response. Given the reciprocal AR-mTOR crosstalk (Wu et al., 2010), everolimus was tested in combination with bicalutamide in two phase II trials that recruited patients with CRPC. In the first one, everolimus was given in combination with bicalutamide both in chemo-naïve and in docetaxel-treated patients (Nakabayashi et al., 2012); this trial showed minimal activity of this combination, but 31 out of 36 enrolled patients had already been treated with bicalutamide before trial enrollment, and might therefore suffer from acquired resistance to this antiandrogen drug. In a more recent trial, the combination of bicalutamide plus everolimus was tested in 24 patients with CRPC naïve to these drugs (Chow et al., 2016); the treatment arm with everolimus and bicalutamide was associated with significant toxicity (58.3\% of patients experienced grade 3 or 4 adverse events, as mucositis, hyperglycemia and hematologic toxicity), but also with a decrease in PSA $\geq 30 \%$ in $75 \%$ of patients; this result is quite comparable to that observed with novel ARS inhibitors (Ryan et al., 2015). Everolimus was also tested in association with docetaxel (Courtney et al., 2015) and carboplatin (Vaishampayan et al., 2015), but showed modest activity in mCRPC. This drug was also evaluated in combination with docetaxel and bevacizumab in patients with CRPC chemo-naïve (Gross et al., 2015); this association demonstrated significant clinical activity (maximal PSA decline $\geq 50 \%$ achieved in 31 (74\%) of patients), but was associated with several hematologic and non-hematologic grade $\geq 3$ toxicities. A phase II trial also explored the efficacy of everolimus plus gefitinib, an epidermal growth factor receptor inhibitor, in patients with CRPC, but did not result in significant antitumor activity (Rathkopf et al., 2015). Ridaforolimus, another mTOR inhibitor, was tested as a single agent in 38 patients with taxane-treated mCRPC; this treatment did not produce objective responses, but stable disease was observed in $47.4 \%$ of patients (Amato et al., 2012). The safety and tolerability of the combination of ridaforolimus plus bicalutamide was assessed in a phase I trial (Meulenbeld et al., 2013); although there was no evidence of a clinically relevant pharmacological drug-drug interaction, the occurrence of dose-limiting toxicities in 3/11 evaluable patients discouraged further studies with this combination. Finally, sapanisertib (MLN0128), a dual mTOR blocker was tested in a phase II trial, which recruited nine heavily pretreated patients with mCRPC (Rathkopf et al., 2016). All patients enrolled had a rise in PSA on treatment with a median of $159 \%$ increase from baseline (range, 12$620 \%$ ), while five patients (56\%) showed an immediate PSA decline upon discontinuation of treatment. This observation suggests activation of the AR in response to dual mTOR inhibition, and confirms the reciprocal link between ARS and PI3K pathways. Recent studies also suggest that PI3K-AKT-mTOR pathway is intimately connected with HIF1 $\alpha$, regulating PC stem cells quiescence and metabolism via the hypoxic signaling (Marhold et al., 2015). Stressful conditions caused by treatments induce activity of the heat shock proteins (HSP) (i.e. HSP90 and HSP27); these chaperones promote the nuclear transport of the AR and are essential for the activation of HIF1 $\alpha$ and hypoxia pathway (Minet et al., 1999; Wyatt and Gleave, 2015). HSP90 inhibitors showed limited activity when administered as monotherapy in patients with mCRPC (Thakur et al., 2016; Wyatt and Gleave, 2015). Conversely, apatorsen, an HSP27 inhibitor, showed good tolerability and encouraging activity in a phase I study (Chi et al., 2016) and the recent data presented at the 2017 Genitourinary Cancers Symposium (ASCO GU) suggest that apatorsen might overcome the resistance to abiraterone in patients with mCRPC (Chi et al., 2017). Given the dual blockade of ARS and hypoxia-inducible factor 1-alpha (HIF1 $\alpha$ ) by HSP inhibitors, the biological contribute of the hypoxia signaling to PC progression remains undefined; the exclusive activation of this pathway is probably relevant only in few PC clones, but these cells might represent the most undifferentiated and resistant populations. Anthracyclines effectively inhibit HIF1 $\alpha$ (Masoud and Li, 2015); the use of these compounds in PC has been limited by toxicity and moderate activity, but some responses have been observed in patients with CRPC (Harris et al., 2002); these data might provide the rationale to renew interest in these chemotherapeutics. In conclusion, preclinical studies support the crucial role of the PI3K/AKT/mTOR pathway in MCRPC, but there is little evidence of clinical benefit with inhibition of this pathway in unselected population of mCRPC. The use of PTEN/AKT/mTOR inhibitors and/or HIF1 $\alpha$ /HSP inhibitors and/or AR modulators may probably be required for efficient pharmaceutical targeting of the most resistant PC clones. Further combination strategies might improve the blockade of this complex pathway, which appears to sustain essential AR-independent metabolic processes (Qin et al., 2012; Robinson et al., 2015; Wyatt and Gleave, 2015). However, the identification of the best combinations of agents depending on the specific characteristics of patients (i.e. PTEN aberrations) is probably the current challenge to be faced.

\subsection{MAPK-ERK pathway}

The MAPK/ERK pathway (also known as the Ras-Raf-MEK-ERK pathway) is a complex system of signal transduction activated by a wide variety of growth factors. Though this pathway is found to be altered only in limited patients with mCRPC (Robinson et al., 2015), its activation generates extensive changes in gene expression, mediated by transcription factors that control tumor cells proliferation, differentiation, migration, and invasion as well as angiogenesis (Dhillon et al., 2007). Whereas activating somatic mutations in the Raf pathway are common in melanoma, Raf fusions ( $3 \%$ of $\mathrm{mCPRC}$ ), rather than mutations, are suggested as a mechanism for Raf gene activation in PC (Palanisamy et al., 2010; Robinson et al., 2015). Several studies investigated the activity of sorafenib, a Raf inhibitor, both in chemotherapy-naïve (Chi et al., 2008; Safarinejad, 2010; Steinbild et al., 2007) and in pretreated unselected populations of patients with mCRPC (Aragon-Ching et al., 2009; Dahut et al., 2008; Nabhan et al., 2012), with discouraging results. Recently, Meyer et al. enrolled 21 patients whose disease had progressed during chemotherapy and added sorafenib to their last chemotherapy regimen (Meyer et al., 2014). They observed biochemical response in 10/21 patients and radiographic stability in $16 / 21$, suggesting that sorafenib may overcome 
chemotherapy-failure among patients with CRPC. Sorafenib combined with enzalutamide exerted a synergistic in vivo inhibitory effect both on AR and ERK pathways; therefore, clinical studies testing sorafenib in the prevention of resistance to enzalutamide are encouraged (Wu et al., 2017). Preclinical models showed that combination of MEK inhibitors with PI3K-AKT-mTOR blockers may exert synergistic activity and efficacy in enzalutamide-resistant CRPC (Park et al., 2015; Toren et al., 2016). A phase II trial is planned to assess the safety and efficacy of the MEK 1/2 inhibitor trametinib in men with progressive mCRPC SingleArm, in press, whereas a randomized phase II trial is comparing the effects of AR inhibition with and without MEK inhibition on the development of EMT in PC Randomized Open-label, 2017 Randomized Open-label, in press, In conclusion, though sorafenib showed limited activity in unselected populations of CRPC, further studies should probably clarify the role of Raf and MEK inhibition in overcoming resistance to standard therapies; in addition, selected patients presenting rearrangements of the Raf gene may benefit from pan-Raf or MEK inhibitors.

\section{DNA-repair pathway}

The accumulation of genetic and epigenetic aberrations characterizes prostate carcinogenesis; these molecular changes can be either inherited or be the result of altered AR transcriptional activity, changes in chromatin architecture, oncogenic replication, error-prone DNA repair, or defective cell division (Mateo et al., 2015). Deficient DNA repair response and defective apoptotic checkpoint control can lead to permanent incorporation of these genome abnormalities, conferring survival and growth advantage to the transformed cell. Deleterious germline or somatic aberrations in genes key to the DNA damage repair pathway (BRCA, CDK12, ATM) were found in $19 \%$ and $23 \%$ of primary PCs and mCRPC, respectively (Network, 2015; Robinson et al., 2015). Recently, Pritchard et al. confirmed that $82(11.8 \%)$ of 692 men with $\mathrm{mPC}$ had at least one presumed pathogenic germline mutation in a gene involved in DNA-repair processes (Pritchard et al., 2016). Germline mutations in ataxia telangiectasia mutated (ATM) and BRCA1/2 are associated with earlier age at death, shorter survival time, and earlier relapse after local treatments in PC (Castro et al., 2015; Na et al., 2016). BRCA2 and BRCA1 also represent about $50 \%$ of all inherited mutations and these alterations are associated with higher risk of nodal involvement, distant metastasis, and poor survival outcomes (Castro et al., 2013). PARP are a family of enzymes involved in the recruitment of DNA repair effectors and modulate transcription processes (Deshmukh and Qiu, 2015). When DNA damage is repairable, PARP-1 recruits proteins involved in DNA repair, whereas when the damage is too severe, the same enzyme leads to cell death (Deshmukh and Qiu, 2015). PARP inhibitors are effective in cells with impairment of DNA repair genes (i.e. BRCA mutations) because of the so-called synthetic lethality. Single strand breaks induced by endogenous damages cannot be effectively repaired in the presence of PARP inhibitors (O'Connor et al., 2007); cells with functional homologous recombination are able to repair more genotoxic double strand breaks, but not BRCA 1 and 2 mutant cells, which undergo cell death (Mateo et al., 2015). Olaparib was the first PARP inhibitor tested in PC. The phase II study TOPARP-A assessed the antitumor activity of this drug in 49 patients who had received at least three lines of therapy for CRPC. Olaparib was well tolerated and led to response in 14 out of 16 patients who had defects in DNA-repair genes, included BRCA1/2, ATM, Fanconi's anemia genes, and CHEK2 (Mateo et al., 2015). Based on these results, the TOPARP-B study is ongoing to prospectively assess the activity of olaparib in patients with aberrations in DNA repair genes (Mateo et al., 2015;TOPARP, in press). PARP inhibition synergizes with AR targeted therapy in preclinical models (Brenner et al., 2011). This is the rationale of a phase II trial that was designed to evaluate the efficacy of veliparib, another PARP inhibitor, plus abiraterone acetate compared to abiraterone acetate alone in patients with mCRPC stratified basing on erythroblast transformation-specific (ETS) gene status; the preliminary results of this combination were presented at the 2016 ASCO Annual Congress (Hussain et al., 2016). Eighteen (27\%) out of 153 randomized patients had homozygous deletions or deleterious mutations in genes involved in DNA repair, BRCA $1 / 2$ and ATM included. The subgroup analysis revealed a better PFS in patients with DNA repair gene alterations as compared to those with an intact DNA-damage-repair system (13.5 months [95\% CI: 8.2-NR] versus 5.8 months [95\% CI: 4.2-8.2]). Other PARP inhibitors, as niraparib and rucaparib, are under investigation in two phase II (Galahad, TRITON 2) and one phase III (TRITON3) trials, respectively, which are enrolling patients with MCRPC with or without impairment of DNA repair genes An Efficacy, 2017 An Efficacy, in press A Study of Rucaparib, in press Study of Rucaparib, in press. DNA damaging agents, as carboplatin, satraplatin and topoisomerase inhibitors showed limited activity in unselected populations of patients with CRPC (Birtle et al., 2004; Buonerba et al., 2014; Klein et al., 2002; Sella et al., 2009; Sternberg et al., 2009). Nevertheless, retrospective analyses and spurious case reports support the notion that DNA defects might confer sensitivity to these treatments (Cheng et al., 2016; Kumar et al., 2016). For this reason, carboplatin monotherapy is considered an acceptable alternative for heavily pretreated CRPC patients, who harbor defects in DNA repair genes (Cheng et al., 2016). PARP inhibitors are suggested to enhance the antitumor activity of cytotoxic therapies and overcome acquired resistance to these drugs ( $\mathrm{O}^{\prime} \mathrm{Connor}$ et al., 2007; Virag and Szabo, 2002). Veliparib was tested in association with temozolomide in a pilot study that enrolled pretreated patients with mCRPC. This combination was well tolerated, but showed limited activity in this unselected population (Hussain et al., 2014). Of note, dose-limiting hematological toxicity was reported when olaparib was combined with chemotherapy in patients with advanced solid tumors (Balmana et al., 2014; Rajan et al., 2012). Therefore, intermittent olaparib with reduced doses of cisplatin was suggested as an alternative combination to improve tolerability (Balmana et al., 2014). Further studies are warranted to assess the potential of PARP inhibitors in combination with cytotoxic agents. For example, olaparib enhanced the sensitivity of Ewing sarcoma bearing EWSR1-ETS fusions to trabectedin in vivo (Ordonez et al., 2015), and patients with CRPC who harbor ETS fusions might be suitable for this combination. EWSR1-ETS fusions mismatch repair (MMR) - deficient tumors appear to be more responsive to PD-1 blockade than MMR - proficient tumors (Le et al., 2015), therefore studies are also needed to assess the role of immunotherapy in the context of CRPCs with MMR alterations. Recently, the anti-PD-1 antibody durvalumab was investigated in combination with olaparib in a phase II trial which enrolled pretreated patients with mCRPC (Karzai et al., 2017). This combination was tolerable and led to PSA response in two out of six patients without BRCA mutation. In conclusion, many mCRPC patients harbor germline or somatic mutations in genes involved in DNA repair which might be predictive of response to DNA damaging agents or PARP inhibitors. Thus, DNA testing warrants clinical consideration in selected subsets of patients.

\section{Cell-cycle pathway}

Several signals (AR, PI3K-AKT, MAPK, Wnt) are integrated and processed by the cell-cycle regulatory machinery, which is responsible of cell division or quiescence (Balk and Knudsen, 2008; Cadoo et al., 2014). Four CDKs regulate the transitions from G2-M-G1-S phases, while the RB product is a critical inhibitor of transition from G1-S phase, preventing premature cell division (Weinberg, 2014). CDKs are responsible of retinoblastoma product (RB) phosphorylation and/or inactivation, allowing the cell to proceed or not with division. RB loss is reported in $21 \%$ of CRPCs and is also implicated in neuroendocrine differentiation of PC (Beltran et al., 2016b; Robinson et al., 2015; Tan et al., 2014). RB inactivation promotes the reprogramming of differentiated cells to a pluripotent state and this supports the notion that the selective pressure, induced by ARS inhibitors and chemotherapy, may 
confer stemness-like features to PC cells (Ellis and Loda, 2015; Kareta et al., 2015). In addition, alterations in genes involved in CDKs regulation were reported in approximately $14 \%$ of CRPC samples (Robinson et al., 2015). All these alterations may be of clinical interest, because the use of CDK-inhibitors would prevent RB phosphorylation, repressing tumor cells proliferation and dedifferentiation (Knudsen and Wang, 2010). Palbociclib and ribociclib are CDK4/6 inhibitors effective in the treatment of advanced breast cancer (Finn et al., 2016; Hortobagyi et al., 2016; Turner et al., 2015). In PC, CDK4/6-specific inhibition reduced tumor proliferation both in vivo and in ex vivo primary human tumors (Comstock et al., 2013). Actually, a phase II study is evaluating the PSA response after treatment with palbociclib plus $\mathrm{ADT}$, compared to ADT alone, in patients with RB-positive mPC REF: A Phase II Study of Androgen Deprivation, in press; a phase II study is also assessing the activity of this CDK inhibitor in an unselected population of CRPCs A Phase II Study of Palbociclib, in press. Ribociclib is under investigation in a phase Ib/II trial, that evaluates the PSA response of ribociclib plus enzalutamide compared to enzalutamide alone in chemotherapy-naïve mCRPC that retains RB expression Enzalutamide, in press.

\section{Developmental pathways}

Processes occurring during tumorigenesis are intimately connected with those observed during embryogenesis and organogenesis (Aiello and Stanger, 2016). Wnt, ERG, YAP/TAZ, Hh, and Notch are key regulators of early development and are also found to be deregulated in PC. These pathways might thus represent potential therapeutic targets for the treatment of this neoplasm.

\subsection{Wnt pathway}

The Wnt pathway is altered in $18 \%$ of patients with mCRPC (Robinson et al., 2015). The Wnt proteins direct cell proliferation and polarity as well as determine a wide range of embryonic patterning events (Sharma et al., 2015). Wnt pathway also promotes EMT-like changes and regulates the expression of factors that are relevant to metastatic progression, notably metalloproteinases and other regulators of the ECM (Anastas and Moon, 2013). In prostate, paracrine Wnt signaling is involved in the interactions between stromal and epithelial cells induced by transforming growth factor-beta (TGF $\beta$ ), modulating androgen sensitivity of epithelial cells (Placencio et al., 2008). In the absence of Wnt ligands, $\beta$-catenin is recruited into a destruction complex, comprised of adenomatous polyposis coli (APC) and axin, which induces the phosphorylation of $\beta$-catenin by casein kinase 1 and glycogen synthase kinase 3 . After activation of the Wnt canonical pathway, $\beta$-catenin escapes proteasomal degradation, accumulates in the cytoplasm and subsequently translocates to the nucleus, where it activates the transcription of Wnt target genes (Lai et al., 2009). R-spondins potentiate Wnt ligand activity as either coactivators or inhibitors of Wnt signaling receptor degradation (Jin and Yoon, 2012). Recurrent alterations of APC, $\beta$-catenin and R-spondin are observed in mCRPC patients (Robinson et al., 2015), supporting the role of this pathway in PC progression. The term non-canonical Wnt pathway has been used in the literature to refer to Wnt-activated signal transduction independent of $\beta$-catenin stabilization (Lai et al., 2009). $\beta$-Catenin-independent Wnt pathways have been proposed to regulate cell polarity and migration, including metastasis (Lai et al., 2009). The RNA-Seq of single prostate circulating tumor cells (CTCs) suggested the strong involvement of noncanonical Wnt signaling in antiandrogen resistance (Miyamoto et al., 2015) and the suppression of its key downstream components, such as Rho kinase, restored partial sensitivity to antiandrogen therapy in vitro (Rath and Olson, 2012). Ursolic acid, a Wnt inhibitor, exerted in vitro antitumor activity and has also been suggested as a chemotherapeutic agent in PC patients (Park et al., 2013). Other studies showed that Mesd, a LRP5/6 co-receptor inhibitor, effectively inhibits PC cells proliferation (Lu et al., 2010) and neutralizing antibodies to Wnt3a reversed PC cells tumorigenesis (Li et al., 2008). Some polyphenols, such as quercetin, epigallocatechin-3-gallat, curcumin and resveratrol, limited PC cell proliferation in in vitro models acting on Wnt signaling; however, their potential clinical implication is controversial (Jasinski et al., 2013). Non-steroidal anti-inflammatory drugs, such as sulindac and celecoxib block the Wnt signaling, decreasing nuclear compartmentalization or enhancing localization of $\beta$-catenin to the plasma membrane (Clapper et al., 2004; Lu et al., 2009). Clinical trials investigated the efficacy of celecoxib and sulindac in combination with chemotherapy in unselected populations of patients with CRPCs, but these drugs did not add any benefit to chemotherapy alone (Carles et al., 2007; Kattan et al., 2016; Ryan et al., 2005; Sinibaldi et al., 2006). Small-molecule therapeutics or even biologics that target the Wnt pathway are still in their infancy and therefore further studies are warranted to understand the potential anti-tumor activity of Wnt pathway inhibition (Kahn, 2014).

\subsection{TMPRSS2/ERG and Hippo pathway}

In 2005, Tomlins et al. reported a recurrent chromosome rearrangement in PC, involving the genes TMPRSS2, localized on chromosome 21q23.2, and ERG, an ETS-related gene localized on chromosome 21q22.2 (Tomlins et al., 2005). Subsequently, the SU2C-PCF International Dream Team confirmed that TMPRSS2/ERG fusion, resulting in ERG overexpression, is observed in about $40 \%$ of advanced PC (Robinson et al., 2015). ERG protein is involved in embryonic development, vascular integrity, cell proliferation, and apoptosis (Han et al., 2015). Several studies investigated the predictive and prognostic role of this aberration in PC. TMPRSS2/ERG fusion was found in peripheral blood mononuclear cells from patients with MCRPC and was associated with resistance to docetaxel and worse prognosis (Reig et al., 2016). Attard et al. suggested that the presence of TMPRSS2/ERG rearrangement in CTCs of mCRPC patients may be predictive of sensitivity to treatment with abiraterone (Attard et al., 2009); in contrast, Danila et al. did not find a correlation between TMPRSS2/ERG status in CTCs and response to abiraterone (Danila et al., 2011). PARP enzymes are necessary for ERG-mediated PC progression and ETS fusion-positive xenografts were shown sensitive to PARP inhibitors in vitro (Brenner et al., 2011). Upon this basis, a phase II trial is evaluating the efficacy of abiraterone plus veliparib compared to abiraterone alone in men with mCRPC stratified for the presence or absence of the TMPRSS2-ERG fusion Abiraterone, in press. Unfortunately, the preliminary results of this trial presented at the 2016 ASCO Annual Congress (Hussain et al., 2016) do not suggest that TMPRSS2-ERG fusion is predictive of response to this combination. Given the supposed sensitivity of TMPRSS2ERG tumors to histone deacetylase inhibitors (Iljin et al., 2006), a phase II trial evaluated the efficacy of pracinostat in an unselected population of 32 CRPC patients (7/21 evaluable patients presented TMPRSS2/ERG fusion), but this drug showed limited activity in this setting of patients (Eigl et al., 2015). Celastrol, a NF-kB inhibitor, was effective in reducing the growth of TMPRSS2/ERG expressing PC in vitro and in vivo (Shao et al., 2013), but currently no clinical trial testing this drug is planned. Recently, Nguyen et al. demonstrated that ERG activates the YAP transcriptional program and induces the development of age-related prostate tumors in mouse models (Nguyen et al., 2015). This result provided direct genetic evidence of a causal role for ERG in PC and revealed a connection between ERG and the Hippo signaling pathway. YAP and TAZ, the main effectors of the Hippo pathway, can reprogram cancer cells into cancer stem cells and incite tumor initiation, progression and metastasis (Piccolo et al., 2014; Zanconato et al., 2016b). TAZ also serves as a downstream element of the Wnt pathway (Azzolin et al., 2012). These transcriptional regulators are transducers of cellular structural features, such as polarity, shape and cytoskeletal organization. In turn, these features are strictly connected to the cell's location in within the tridimensional architecture of tissues, including the 
attachment to other cells and to the ECM (Zanconato et al., 2016b). First reports in 2007 showed that PC tissues have significant elevation of YAP protein levels and these data are confirmed by in vitro studies (Sheng et al., 2015; Zhang et al., 2015; Zhao et al., 2007). Tankyrase inhibitors, statins, bisphosphonates, geranylgeranyl transferase- 1 and G-proteins inhibitors are suggested as modulators of YAP/TAZ pathway (Zanconato et al., 2016a); however, the pharmacological inhibition of this pathway remains challenging, as many interactions specifically involved in the control of YAP/TAZ activity may be difficult to target (Zanconato et al., 2016a).

\subsection{Hh and Notch pathways}

Hh signaling, as well as Wnt pathway, is suggested to modulate stem cells characteristics (Kalderon, 2002; Taipale and Beachy, 2001). In PC, Hh cascade regulates epithelial-mesenchymal interactions, cell survival, angiogenesis and metastatic potential of cells (Karhadkar et al., 2004). Antonarakis et al. evaluated the efficacy of high-dose itraconazole, an Hh pathway inhibitor, in men with metastatic chemotherapyuntreated CRPC; this drug showed modest clinical activity, as suggested by longer PFS times than in historical data (Antonarakis et al., 2013). TAK-441 and vismodegib are selective Smo antagonists and delayed progression of PC in vivo models, by disrupting paracrine hedgehog signaling (Ibuki et al., 2013; Karlou et al., 2012); some trials are ongoing to assess the efficacy of vismodegib in men with CRPC Leuprolide, in press A Study of Vismodegib, in press. Also, two smallmolecule antagonists of Hh pathway inhibithed PC proliferation in in vitro and in vivo models, but no clinical application has yet been tested (Lauth et al., 2007). Notch signaling is another developmental pathway, which regulates organogenesis, cell death and tissue homeostasis (Su and Xin, 2016). Notch synergizes with several pathways, as AKT, Wnt, Ras/Raf/MAPK, and contributes to the development and progression of PC (Stoyanova et al., 2016). Both tumor suppressive and oncogenic roles of Notch have limited the investigation of Notch inhibitors for PC and probably more studies are needed to understand the therapeutic potential of this signaling pathway (Su and Xin, 2016; Yuan et al., 2015).

\section{Neuroendrocrine differentiation}

Neuroendocrine differentiation of PCs is estimated to drive approximately $25 \%$ of the nearly 34,000 cases of lethal PC in the United States per year (Jemal et al., 2011). Divergent clonal evolution from one or more CRPC adenocarcinoma cells has been suggested as the main mechanism of development of NEPC (Beltran et al., 2016b). With the growing clinical use of ARS inhibitors, a subset of resistant tumors shows reduced or absent AR expression and small-cell carcinoma or neuroendocrine features (chromogranin A, synaptophysin and neural cell adhesion molecule) on metastatic biopsy (Beltran et al., 2011; Palmgren et al., 2007; Watson et al., 2015). Molecular profiling of NEPC has revealed loss of RB1, PTEN and tumor protein p53 (p53) mutations as well as amplification of MYCN and AURKA (Beltran et al., 2011; Tan et al., 2014). Unfortunately, the development of NEPC is associated with a poor survival of patients due to lack of effective treatments available (Mosquera et al., 2013). Based on the clinical efficacy observed in neuroendocrine lung cancer, the use of platinumbased chemotherapy has been suggested in NEPC; however, this treatment strategy is characterized by a high response rate of short duration (Aparicio et al., 2013). Recently, Beltran et al. evaluated the activity and safety of alisertib, an AURKA inhibitor, in a phase II study, that enrolled 59 patients with metastatic NEPC (Beltran et al., 2016a). Based on the previously developed integrated 70-gene NEPC classifier (Beltran et al., 2016b), they showed high correlation of molecular alterations (AURKA/MYCN, AR signaling, RB1/TP53) with clinical-pathological features and exceptional responders. Although the trial did not meet its primary endpoint, which was PFS, the authors concluded that a specific subset of patients with clinical-pathologically defined NEPC may benefit from alisertib monotherapy. MYCN levels are regulated by bromodomain and extra-terminal proteins (BET) proteins and the BET inhibitors were effective in reducing the growth of CRPC in vitro and in vivo (Asangani et al., 2014; Wyce et al., 2013). In addition, BET inhibitors were recently shown to enhance the efficacy and disrupt resistance to AR antagonists in CRPCs, providing a compelling rationale to combine BET inhibitors with AR antagonists in clinical trials (Asangani et al., 2016).

\section{Tumor microenvironment and immunotherapy}

Normal tissue homeostasis and architecture physiologically inhibit cancer development and progression; therefore, tumor expansion and dissemination assumes an impaired control of all those transcriptional regulators that are modulated by a complex interchange of information among cells in the local microenvironment (Bissell and Hines, 2011). The ECM provides not only architectural support, but also chemical and mechanical cues to cells; several proteins (i.e. periostin, tenascin-C, versican), growth factors (i.e. TGF $\beta$, epidermal growth factor, vascular endothelial growth factor, hepatocyte growth factor), interleukins as well as ECM stiffness influence the tumor microenvironment (Barron and Rowley, 2012; Bonnans et al., 2014; Nuzzo et al., 2014; Pickup et al., 2013). All these factors modulate PC cell proliferation and induce EMT through multiple signals, including the JAK-STAT, the SMAD, the MAPK and the PI3K pathway (Nguyen et al., 2014; Pickup et al., 2013). The serum levels of interleukin- 6 and TGF $\beta$ are associated with PC progression, metastases and poor survival of patients (Shariat et al., 2004; Shariat et al., 2011). These markers are surrogated of chronic inflammation and a potential link between prostatitis, prostatic infections and the development of PC was suggested (Sfanos and De Marzo, 2012). Differently from melanoma and other neoplasms, which show high rates of somatic mutations and are considered good targets for immunotherapy, the mutational load of PC cells has been historically considered low (Schumacher and Schreiber, 2015). However, growing evidence suggests that MCRPC show higher mutational load compared with primary tumors (Drake, 2010; Robinson et al., 2015; Taylor et al., 2010). Many immunotherapy approaches share the common goal of inducing a specific T-cell response directed against the tumor cells and reversing their resistance to adaptive immunity (Drake, 2010; Ribas, 2015). The first successful achievement in PC immunotherapy was the development of Sipuleucel-T. This cell-based vaccine was approved in 2010 by the U.S. Food and Drug Administration for the treatment of mCRPC, given a 4-month OS improvement reported in the phase III trial IMPACT, which randomized 512 patients with MCRPC in a 2:1 ratio to receive either Sipuleucel-T or placebo (Kantoff et al., 2010). Based on this, Sipuleucel-T is widely included among the treatment options for patients with minimally symptomatic or asymptomatic mCRPC NCCN, 2017. Nevertheless, the Society for Immunotherapy of Cancer underscores that there is still no absolute consensus on the utilization of Sipuleucel-T regarding several aspects, including sequencing immunotherapy with other treatments and monitoring of response, and that recommendations still need to be improved (McNeel et al., 2016). In particular, in an era when several new ARS inhibitors are becoming increasingly available for the treatment of mCRPC, an interesting challenge will be to fit the use of Sipuleucel-T in the most appropriate temporal frame over the disease course, and to select the optimal subset of patients that may derive a greater benefit from it. Moreover, even though a direct cost comparison with other agents is difficult, especially over the complete course of treatment, Sipuleucel-T represents an expensive option. Some other vaccines achieved promising results in mCRPC patients in phase I/II trials, with mild side effects, and many others are currently under investigation (Cattrini et al., 2016). For example, the randomized, phase III trials VIABLE Phase III, in press and PROSPECT Randomized and Double-blind, in press are ongoing to evaluate the efficacy and safety of a dendritic-cell based vaccine 
(DCVAC/PCa) and of a vector-based vaccine (PROSTVAC), respectively, in men with mCRPC eligible for first-line chemotherapy. Even though initial phase I/II trials showed promising results with the use of the anti-CTLA-4 antibody ipilimumab (Cha and Small, 2013), a randomized phase III trial failed to show an OS benefit when this agent was used alone for patients with MCRPC in the post-docetaxel setting (Kwon et al., 2014). Nevertheless, in a retrospective subgroup analysis of this study, OS was 22.7 months among a small cohort of ipilimumab-treated patients with favorable prognostic features (namely, patients with nonvisceral disease, alkaline-phospatase $<1.5$ times the upper limit of normal and hemoglobin of at least $11.5 \mathrm{~g} / \mathrm{dL}$ ) as compared to 15.8 months in the placebo group. Also, ipilimumab did not improve OS in patients with chemotherapy-naive mCRPC in a phase III trial that enrolled 598 patients to receive ipilimumab or placebo (2:1) (Beer et al., 2016). Two phase I trials evaluated the activity of the anti-PD-1 antibody nivolumab as a single agent in heavily pre-treated advanced malignancies, but failed to show objective responses in the PC cohort (Brahmer et al., 2010; Topalian et al., 2012). The Keynote-028 Study was designed to evaluate the safety and efficacy of the anti-PD-1 pembrolizumab monotherapy in PD-L1-positive advanced solid tumor cohorts (Hansen et al., 2016). The preliminary results from the PC cohort of this phase $1 \mathrm{~b}$ study ( 23 patients) reported an ORR of $13 \%$, but $45 \%$ of evaluable patients had a decrease from baseline in the sum of longest diameters of target lesions. Exploratory assessment of the relationship between gene expression profile score and clinical outcome revealed the putative $\mathrm{T}$ cell inflamed signature to be associated with better clinical outcome (Hansen et al., 2016). Bishop et al. observed that resistance to enzalutamide is associated with the strong expression of anti-PD-1 therapy targets in circulating immune cells both in mCRPC patients and in pre-clinical models (Bishop et al., 2015). On this basis, Graff et al. treated 20 mCRPC patients who progressed on enzalutamide with pembrolizumab $200 \mathrm{mg}$ IV every 3 weeks for 4 doses (Graff et al., 2016a); of note, pembrolizumab was added to and did not replace the standard dose of enzalutamide. $20 \%$ of patients (4/20) showed remarkable long-lasting PSA responses and 35\% (7/20) had stable disease ranging 9-50 weeks (Graff et al., 2016b). In vitro studies support that ADT may sensitize prostate cancer cells to T-cell killing through androgen receptor dependent modulation of the apoptotic pathway (Ardiani et al., 2014). These clinical data confirm that primary and secondary ADT may stimulate $\mathrm{T}$ cell infiltrates, synergizing with immunotherapeutics. In addition, the genetic analysis of two responders revealed markers of microsatellite instability in one patient, suggesting that patients with DNA repair genes alterations may also be candidates to these treatments (Graff et al., 2016b). Recent data also revealed that bone metastases from PC, with low AR expression and reduced metabolic activity, show high MHC class I expression and immune cell infiltration; this supports the rationale for treating specific PC patients with combinations of ADT and immunotherapy (Ylitalo et al., 2016). In conclusion, to date there are no prospective data to support monotherapy with either an anti-CTLA-4 or anti-PD-1 agents in patients with mCRPC. However, these immunotherapeutics appear to be effective in specific subgroups of patients; probably, the identification of synergies with ARS inhibitors or other drugs, as well as their correct implementation in the sequence of agents currently used in CRPC, may uncover unexpected potentialities of these new compounds. This notion is guiding the experimental design of new trials, such as the Keynote199 study, which is recruiting 250 men with mCRPC to assess the activity of pembrolizumab in patients previously treated with chemotherapy Study of Pembrolizumab, in press; this study has three planned cohorts: participants with PD-L1-positive, measurable disease; participants with PD-L1 negative, measurable disease; participants with bone-metastases, non-measurable disease. The discovery of novel biomarkers of response may also help the selection of those cases candidates for immunotherapy.

\section{Conclusions}

The majority of treatments that are currently used in clinical practice to treat patients with PC modulate the ARS pathway. The increased heterogeneity, phenotypic plasticity, and genomic variability of PC cells in the setting of advanced disease are frequently responsible of resistance to treatment. Several studies suggest that AR is still activated after progression on AR-directed therapies and that it still plays a role in advanced and heavily pretreated CRPC. However, many pathways, both AR related and non-AR related, can contribute to progression of CRPC. In some cases, AR-independent pathways provide sustenance for the growth of aggressive tumor cells with high metastatic potential. Many non-AR-directed drugs have been tested in CRPC, mostly as monotherapy or in unselected populations of patients, and studies yielded conflicting results. Predictive markers of response are therefore needed to avoid the failure of future trials, and to properly select patients that would most likely benefit from non-AR-targeted therapies. For example, in the years to come, liquid biopsies might help identify these subsets of patients, offering new therapeutic opportunities for those with poor baseline prognostic features or primary as well as acquired resistance to hormone-therapies. In addition, studies evaluating combinations of ARS modulators or chemotherapy with compounds that target AR-independent pathways may provide new insight on the treatment options for both early and advanced PC.

\section{Conflicts of interest statement}

The authors declare no conflicts of interest.

\section{References}

Abiraterone Acetate and Prednisone With or Without Veliparib in Treating Patients With Metastatic Hormone-Resistant Prostate Cancer. NCT01576172. ClinicalTrials.gov.

An Efficacy and Safety Study of Niraparib in Men With Metastatic Castration-Resistant Prostate Cancer and DNA-Repair Anomalies. NCT02854436. ClinicalTrials.gov.

A Phase II Study of Androgen Deprivation Therapy With or Without Palbociclib in RBPositive Metastatic Prostate Cancer. NCT02059213. ClinicalTrials.gov.

A Phase II Study of Palbociclib, A CDK4/6 Inhibitor, in Patients With Metastatic Castration-Resistant Prostate Cancer NCT02905318. ClinicalTrials.gov. Canadian Cancer Trials Group.

A Study of Rucaparib in Patients With Metastatic Castration-resistant Prostate Cancer and Homologous Recombination Gene Deficiency (TRITON2). NCT02952534. ClinicalTrials.gov.

A Study of Rucaparib Verses Physician's Choice of Therapy in Patients With Metastatic Castration-resistant Prostate Cancer and Homologous Recombination Gene Deficiency (TRITON3). NCT02975934. ClinicalTrials.gov.

A Study of Vismodegib in Men With Metastatic CRPC With Accessible Metastatic Lesions for Tumor Biopsy. NCT02115828. ClinicalTrials.gov.

Aiello, N.M., Stanger, B.Z., 2016. Echoes of the embryo: using the developmental biology toolkit to study cancer. Dis. Models Mech. 9 (2), 105-114.

Amato, R.J., Wilding, G., Bubley, G., Loewy, J., Haluska, F., Gross, M.E., 2012. Safety and preliminary efficacy analysis of the mTOR inhibitor ridaforolimus in patients with taxane-treated, castration-resistant prostate cancer. Clin. Genitourin Cancer 10 (4), 232-238.

Anastas, J.N., Moon, R.T., 2013. WNT signalling pathways as therapeutic targets in cancer. Nat. Rev. Cancer 13 (1), 11-26.

Antonarakis, E.S., Heath, E.I., Smith, D.C., Rathkopf, D., Blackford, A.L., Danila, D.C., King, S., Frost, A., Ajiboye, A.S., Zhao, M., Mendonca, J., Kachhap, S.K., Rudek, M.A. Carducci, M.A., 2013. Repurposing itraconazole as a treatment for advanced prostate cancer: a noncomparative randomized phase II trial in men with metastatic castration-resistant prostate cancer. Oncologist 18 (2), 163-173.

Aparicio, A.M., Harzstark, A.L., Corn, P.G., Wen, S., Araujo, J.C., Tu, S.M., Pagliaro, L.C., Kim, J., Millikan, R.E., Ryan, C., Tannir, N.M., Zurita, A.J., Mathew, P., Arap, W., Troncoso, P., Thall, P.F., Logothetis, C.J., 2013. Platinum-based chemotherapy for variant castrate-resistant prostate cancer. Clin. Cancer Res. 19 (13), 3621-3630.

Aragon-Ching, J.B., Jain, L., Gulley, J.L., Arlen, P.M., Wright, J.J., Steinberg, S.M., Draper, D., Venitz, J., Jones, E., Chen, C.C., Figg, W.D., Dahut, W.L., 2009. Final analysis of a phase II trial using sorafenib for metastatic castration-resistant prostate cancer. BJU Int. 103 (12), 1636-1640.

Ardiani, A., Gameiro, S.R., Kwilas, A.R., Donahue, R.N., Hodge, J.W., 2014. Androgen deprivation therapy sensitizes prostate cancer cells to T-cell killing through androgen receptor dependent modulation of the apoptotic pathway. Oncotarget 5 (19), 9335-9348.

Armstrong, A.J., Halabi, S., Healy, P., Alumkal, J.J., Yu, E.Y., Winters, C., Hobbs, C., Soleau, C., Slottke, R., Mundy, K., George, D.J., 2015. Phase II trial of the PI3 kinase inhibitor BKM120 with or without enzalutamide in men with metastatic castration resistant prostate cancer (mCRPC). J. Clin. Oncol. 33 (Suppl) abstr. 5025.

Armstrong, A.J., Shen, T., Halabi, S., Kemeny, G., Bitting, R.L., Kartcheske, P., Embree, E., Morris, K., Winters, C., Jaffe, T., Fleming, M., George, D.J., 2013. A phase II trial of 
temsirolimus in men with castration-resistant metastatic prostate cancer. Clin. Genitourin Cancer 11 (4), 397-406.

Asangani, I.A., Dommeti, V.L., Wang, X., Malik, R., Cieslik, M., Yang, R., Escara-Wilke, J., Wilder-Romans, K., Dhanireddy, S., Engelke, C., Iyer, M.K., Jing, X., Wu, Y.M., Cao, X., Qin, Z.S., Wang, S., Feng, F.Y., Chinnaiyan, A.M., 2014. Therapeutic targeting of BET bromodomain proteins in castration-resistant prostate cancer. Nature 510 (7504), 278-282.

Asangani, I.A., Wilder-Romans, K., Dommeti, V.L., Krishnamurthy, P.M., Apel, I.J., Escara-Wilke, J., Plymate, S.R., Navone, N.M., Wang, S., Feng, F.Y., Chinnaiyan, A.M., 2016. BET bromodomain inhibitors enhance efficacy and disrupt resistance to AR antagonists in the treatment of prostate cancer. Mol. Cancer Res.: MCR 14 (4), 324-331.

Attard, G., Swennenhuis, J.F., Olmos, D., Reid, A.H., Vickers, E., A'Hern, R., Levink, R. Coumans, F., Moreira, J., Riisnaes, R., Oommen, N.B., Hawche, G., Jameson, C., Thompson, E., Sipkema, R., Carden, C.P., Parker, C., Dearnaley, D., Kaye, S.B., Cooper, C.S., Molina, A., Cox, M.E., Terstappen, L.W., de Bono, J.S., 2009. Characterization of ERG, AR and PTEN gene status in circulating tumor cells from patients with castration-resistant prostate cancer. Cancer Res. 69 (7), 2912-2918.

Azzolin, L., Zanconato, F., Bresolin, S., Forcato, M., Basso, G., Bicciato, S., Cordenonsi, M., Piccolo, S., 2012. Role of TAZ as mediator of Wnt signaling. Cell 151 (7), 1443-1456.

Balk, S.P., Knudsen, K.E., 2008. AR, the cell cycle, and prostate cancer. Nuclear Receptor Signal. 6, e001.

Balmana, J., Tung, N.M., Isakoff, S.J., Grana, B., Ryan, P.D., Saura, C., Lowe, E.S., Frewer, P., Winer, E., Baselga, J., Garber, J.E., 2014. Phase I trial of olaparib in combination with cisplatin for the treatment of patients with advanced breast, ovarian and other solid tumors. Ann. Oncol. 25 (8), 1656-1663.

Barron, D.A., Rowley, D.R., 2012. The reactive stroma microenvironment and prostate cancer progression. Endocr. Relat. Cancer 19 (6), R187-R204.

Beer, T.M., Kwon, E.D., Drake, C.G., Fizazi, K., Logothetis, C., Gravis, G., Ganju, V., Polikoff, J., Saad, F., Humanski, P., Piulats, J.M., Mella, P.G., Ng, S.S., Jaeger, D., Parnis, F.X., Franke, F.A., Puente, J., Carvajal, R., Sengeløv, L., McHenry, M.B., Varma, A., van den Eertwegh, A.J., Gerritsen, W., 2016. Randomized, double-blind, Phase III trial of ipilimumab versus placebo in asymptomatic or minimally symptomatic patients with metastatic chemotherapy-naive castration-resistant prostate cancer. J. Clin. Oncol.

Beltran, H., Danila, D., Montgomery, B., Szmulewitz, R., Vaishampayan, U., Armstrong, A., Stein, M., Hoimes, C., Pinski, J., Scher, H., Puca, L., Bareja, R., Wong, W., Rubin, M., Mosquera, J.M., Sboner, A., Oromendia, C., Nanus, D., Ballman, K., Tagawa, S.T., 2016a. A phase 2 study of the aurora kinase A inhibitor alisertib for patients with neuroendocrine prostate cancer (NEPC). Ann. Oncol. 27 (Suppl. 6), 552-587.

Beltran, H., Prandi, D., Mosquera, J.M., Benelli, M., Puca, L., Cyrta, J., Marotz, C., Giannopoulou, E., Chakravarthi, B.V., Varambally, S., Tomlins, S.A., Nanus, D.M., Tagawa, S.T., Van Allen, E.M., Elemento, O., Sboner, A., Garraway, L.A., Rubin, M.A., Demichelis, F., 2016b. Divergent clonal evolution of castration-resistant neuroendocrine prostate cancer. Nat. Med. 22 (3), 298-305.

Beltran, H., Rickman, D.S., Park, K., Chae, S.S., Sboner, A., MacDonald, T.Y., Wang, Y., Sheikh, K.L., Terry, S., Tagawa, S.T., Dhir, R., Nelson, J.B., de la Taille, A., Allory, Y., Gerstein, M.B., Perner, S., Pienta, K.J., Chinnaiyan, A.M., Wang, Y., Collins, C.C., Gleave, M.E., Demichelis, F., Nanus, D.M., Rubin, M.A., 2011. Molecular characterization of neuroendocrine prostate cancer and identification of new drug targets. Cancer Discov. 1 (6), 487-495.

Birtle, A.J., Newby, J.C., Harland, S.J., 2004. Epirubicin carboplatin and 5-fluorouraci (ECarboF) chemotherapy in metastatic hormone refractory prostate cancer. Br. J. Cancer 91 (8), 1472-1476.

Bishop, J.L., Sio, A., Angeles, A., Roberts, M.E., Azad, A.A., Chi, K.N., Zoubeidi, A., 2015. PD-L1 is highly expressed in Enzalutamide resistant prostate cancer. Oncotarget 6 (1), 234-242.

Bissell, M.J., Hines, W.C., 2011. Why don't we get more cancer? A proposed role of the microenvironment in restraining cancer progression. Nat. Med. 17 (3), 320-329.

Bitting, R.L., Armstrong, A.J., 2013. Targeting the PI3K/Akt/mTOR pathway in castration-resistant prostate cancer. Endocr. Relat. Cancer 20 (3), R83-R99.

Bonnans, C., Chou, J., Werb, Z., 2014. Remodelling the extracellular matrix in development and disease. Nat. Rev. Mol. Cell Biol. 15 (12), 786-801.

Boyd, L.K., Mao, X., Lu, Y.J., 2012. The complexity of prostate cancer: genomic alterations and heterogeneity. Nat. Rev. Urol. 9 (11), 652-664.

Brahmer, J.R., Drake, C.G., Wollner, I., Powderly, J.D., Picus, J., Sharfman, W.H., Stankevich, E., Pons, A., Salay, T.M., McMiller, T.L., Gilson, M.M., Wang, C., Selby, M., Taube, J.M., Anders, R., Chen, L., Korman, A.J., Pardoll, D.M., Lowy, I., Topalian, S.L., 2010. Phase I study of single-agent anti-programmed death-1 (MDX-1106) in refractory solid tumors: safety, clinical activity, pharmacodynamics, and immunologic correlates. J. Clin. Oncol. 28 (19), 3167-3175.

Brenner, J.C., Ateeq, B., Li, Y., Yocum, A.K., Cao, Q., Asangani, I.A., Patel, S., Wang, X., Liang, H., Yu, J., Palanisamy, N., Siddiqui, J., Yan, W., Cao, X., Mehra, R., Sabolch, A., Basrur, V., Lonigro, R.J., Yang, J., Tomlins, S.A., Maher, C.A., Elenitoba-Johnson, K.S., Hussain, M., Navone, N.M., Pienta, K.J., Varambally, S., Feng, F.Y., Chinnaiyan, A.M., 2011. Mechanistic rationale for inhibition of poly(ADP-ribose) polymerase in ETS gene fusion-positive prostate cancer. Cancer Cell 19 (5), 664-678.

Buonerba, C., Federico, P., Bosso, D., Puglia, L., Policastro, T., Izzo, M., Perri, F., Vittoria Scarpati, G.D., Ferro, M., Cobelli, O.D., De Placido, S., Aieta, M., Imbimbo, C., Longo, N., Di Lorenzo, G., 2014. Carboplatin plus etoposide in heavily pretreated castrationresistant prostate cancer patients. Fut. Oncol. (Lond., Engl.) 10 (8), 1353-1360.

Cadoo, K.A., Gucalp, A., Traina, T.A., 2014. Palbociclib: an evidence-based review of its potential in the treatment of breast cancer. Breast Cancer (Dove Med. Press) 6, 123-133.

Carles, J., Font, A., Mellado, B., Domenech, M., Gallardo, E., Gonzalez-Larriba, J.L., Catalan, G., Alfaro, J., Gonzalez Del Alba, A., Nogue, M., Lianes, P., Tello, J.M., 2007. Weekly administration of docetaxel in combination with estramustine and celecoxib in patients with advanced hormone-refractory prostate cancer: final results from a phase II study. Br. J. Cancer 97 (9), 1206-1210.

Castro, E., Goh, C., Leongamornlert, D., Saunders, E., Tymrakiewicz, M., Dadaev, T., Govindasami, K., Guy, M., Ellis, S., Frost, D., Bancroft, E., Cole, T., Tischkowitz, M.,
Kennedy, M.J., Eason, J., Brewer, C., Evans, D.G., Davidson, R., Eccles, D., Porteous, M.E., Douglas, F., Adlard, J., Donaldson, A., Antoniou, A.C., Kote-Jarai, Z., Easton, D.F., Olmos, D., Eeles, R., 2015. Effect of BRCA mutations on metastatic relapse and cause-specific survival after radical treatment for localised prostate cancer. Eur. Urol. 68 (2), 186-193.

Castro, E., Goh, C., Olmos, D., Saunders, E., Leongamornlert, D., Tymrakiewicz, M., Mahmud, N., Dadaev, T., Govindasami, K., Guy, M., Sawyer, E., Wilkinson, R., Ardern-Jones, A., Ellis, S., Frost, D., Peock, S., Evans, D.G., Tischkowitz, M., Cole, T., Davidson, R., Eccles, D., Brewer, C., Douglas, F., Porteous, M.E., Donaldson, A., Dorkins, H., Izatt, L., Cook, J., Hodgson, S., Kennedy, M.J., Side, L.E., Eason, J., Murray, A., Antoniou, A.C., Easton, D.F., Kote-Jarai, Z., Eeles, R., 2013. Germline BRCA mutations are associated with higher risk of nodal involvement, distant metastasis, and poor survival outcomes in prostate cancer. J. Clin. Oncol. 31 (14), 1748-1757.

Cattrini, C., Dellepiane, C., Cavo, A., Buzzatti, G., Tolomeo, F., Messina, C., Boccardo, F, 2016. Immunotherapy for genitourinary cancer: state of the art and new perspectives. Anti-Cancer Drugs 27 (7), 585-599.

Cha, E., Small, E.J., 2013. Is there a role for immune checkpoint blockade with ipilimumab in prostate cancer? Cancer Med. 2 (2), 243-252.

Cheng, H.H., Pritchard, C.C., Boyd, T., Nelson, P.S., Montgomery, B., 2016. Biallelic inactivation of BRCA2 in platinum-sensitive metastatic castration-resistant prostate cancer. Eur. Urol. 69 (6), 992-995.

Chi, K.N., Ellard, S.L., Hotte, S.J., Czaykowski, P., Moore, M., Ruether, J.D., Schell, A.J., Taylor, S., Hansen, C., Gauthier, I., Walsh, W., Seymour, L., 2008. A phase II study of sorafenib in patients with chemo-naive castration-resistant prostate cancer. Ann. Oncol. 19 (4), 746-751.

Chi, K.N., Fleming, M.T., Sunderland, K., Albany, C., Gingerich, J., Saad, F., North, S.A. Starodub, A., Lauer, R.C., 2017. PACIFIC trial: a randomized phase II study of apatorsen and abiraterone in patients (Pts) with metastatic castration-resistant prostate cancer (mCRPC) who have had PSA progression while receiving abiraterone (ABI). J. Clin. Oncol. 35 (Suppl. 6S) abstr. 146.

Chi, K.N., Yu, E.Y., Jacobs, C., Bazov, J., Kollmannsberger, C., Higano, C.S., Mukherjee, S.D., Gleave, M.E., Stewart, P.S., Hotte, S.J., 2016. A phase I dose-escalation study of apatorsen (OGX-427), an antisense inhibitor targeting heat shock protein 27 (Hsp27), in patients with castration-resistant prostate cancer and other advanced cancers. Ann. Oncol. 27 (6), 1116-1122.

Chow, H., Ghosh, P.M., deVere White, R., Evans, C.P., Dall'Era, M.A., Yap, S.A., Li, Y, Beckett, L.A., Lara Jr., P.N., Pan, C.X., 2016. A phase 2 clinical trial of everolimus plus bicalutamide for castration-resistant prostate cancer. Cancer 122 (12), 1897-1904.

Clapper, M.L., Coudry, J., Chang, W.C., 2004 beta-catenin-mediated signaling: a molecular target for early chemopreventive intervention. Mut. Res. 555 (1-2), 97-105.

Comstock, C.E., Augello, M.A., Goodwin, J.F., de Leeuw, R., Schiewer, M.J., Ostrander Jr., W.F., Burkhart, R.A., McClendon, A.K., McCue, P.A., Trabulsi, E.J., Lallas, C.D., Gomella, L.G., Centenera, M.M., Brody, J.R., Butler, L.M., Tilley, W.D., Knudsen, K.E., 2013. Targeting cell cycle and hormone receptor pathways in cancer. Oncogene 32 (48), 5481-5491.

Courtney, K.D., Manola, J.B., Elfiky, A.A., Ross, R., Oh, W.K., Yap, J.T., Van den Abbeele A.D., Ryan, C.W., Beer, T.M., Loda, M., Priolo, C., Kantoff, P., Taplin, M.E., 2015. A phase I study of everolimus and docetaxel in patients with castration-resistant prostate cancer. Clin. Genitourin Cancer 13 (2), 113-123.

Crabb, S.J., Birtle, A.J., Martin, K., Downs, N., Ratcliffe, I., Maishman, T., Ellis, M., Griffiths, G., Thompson, S., Ksiazek, L., Khoo, V., Jones, R.J., 2017. ProCAID: a phase I clinical trial to combine the AKT inhibitor AZD5363 with docetaxel and prednisolone chemotherapy for metastatic castration resistant prostate cancer. Invest. New Drugs.

Dahut, W.L., Scripture, C., Posadas, E., Jain, L., Gulley, J.L., Arlen, P.M., Wright, J.J., Yu, Y., Cao, L., Steinberg, S.M., Aragon-Ching, J.B., Venitz, J., Jones, E., Chen, C.C., Figg, W.D., 2008. A phase II clinical trial of sorafenib in androgen-independent prostate cancer. Clin. Cancer Res 14 (1), 209-214.

Danila, D.C., Anand, A., Sung, C.C., Heller, G., Leversha, M.A., Cao, L., Lilja, H., Molina, A., Sawyers, C.L., Fleisher, M., Scher, H.I., 2011. TMPRSS2-ERG status in circulating tumor cells as a predictive biomarker of sensitivity in castration-resistant prostate cancer patients treated with abiraterone acetate. Eur. Urol. 60 (5), 897-904.

De Bono, J.S., De Giorgi, U., Massard, C., Bracarda, S., Kocak, I., Font, A., Arranz Arija, J.A., Shih, K.C., Radavoi, G.D., Yu, W., Chan, W.Y., Huang, J., Musib, L.C., Gendreau, S., Meng, R.D., Patel, P.H., Maslyar, D.J., Jinga, V., 2016a. Randomized phase II study of AKT blockade with ipatasertib (GDC-0068) and abiraterone (Abi) vs. abi alone in patients with metastatic castration-resistant prostate cancer (mCRPC) after docetaxel chemotherapy (A. MARTIN Study). J. Clin. Oncol. 34 (Suppl) abstr. 5017.

De Bono, J.S., De Giorgi, U., Massard, C., Bracarda, S., Nava Rodrigues, D., Kocak, I., Font, A., Arranz Arija, J., Shih, K., Radavoi, G.D., Yu, W., Chan, W., Gendreau, S., Zhang, L., Riisnaes, R., Wongchenko, M.J., D.M.V.J, 2016b. PTEN loss as a predictive biomarker for the Akt inhibitor ipatasertib combined with abiraterone acetate in patients with metastatic castration-resistant prostate cancer (mCRPC). Ann. Oncol. 27 (Suppl. 6).

Deshmukh, D., Qiu, Y., 2015. Role of PARP-1 in prostate cancer. Am. J. Clin. Exp. Urol. 3 (1), 1-12.

Dhillon, A.S., Hagan, S., Rath, O., Kolch, W., 2007. MAP kinase signalling pathways in cancer. Oncogene 26 (22), 3279-3290.

Drake, C.G., 2010. Immunotherapy for prostate cancer: an emerging treatment modality. Urol. Clin. North Am. 37 (1), 121-129 Table of Contents.

Enzalutamide With and Without Ribociclib for Metastatic, Castrate-Resistant, Chemotherapy-Naive Prostate Cancer That Retains RB Expression. NCT02555189. ClinicalTrials.gov.

Eigl, B.J., North, S., Winquist, E., Finch, D., Wood, L., Sridhar, S.S., Powers, J., Good, J., Sharma, M., Squire, J.A., Bazov, J., Jamaspishvili, T., Cox, M.E., Bradbury, P.A. Eisenhauer, E.A., Chi, K.N., 2015. A phase II study of the HDAC inhibitor SB939 in patients with castration resistant prostate cancer: NCIC clinical trials group study IND195. Investig. New Drugs 33 (4), 969-976.

Ellis, L., Loda, M., 2015. Advanced neuroendocrine prostate tumors regress to stemness. 
Proc. Natl. Acad. Sci. U. S. A. 112 (47), 14406-14407.

Emmenegger, U., Booth, C.M., Berry, S., Sridhar, S.S., Winquist, E., Bandali, N., Chow, A., Lee, C., Xu, P., Man, S., Kerbel, R.S., Ko, Y.J., 2015. Temsirolimus maintenance therapy after docetaxel induction in castration-resistant prostate cancer. Oncologist 20 (12), 1351-1352.

Feng, F.Y., Zhao, S., Chang, S.L., Erho, N., Lehrer, J., Alshalalfa, M., Cooperberg, M.R., Kim, W., Ryan, C.J., 2017. Luminal and basal subtyping of prostate cancer. J. Clin. Oncol. 35 (Suppl. 6S) abstr. 3.

Finn, R.S., Martin, M., Rugo, H.S., Jones, S., Im, S.-A., Gelmon, K., Harbeck, N., 2016. Palbociclib and letrozole in advanced breast cancer. N. Engl. J. Med. 375, 1925-1936.

Fruman, D.A., Rommel, C., 2014. PI3K and cancer: lessons, challenges and opportunities. Nat. Rev. Drug Discov. 13 (2), 140-156.

Graff, J.N., Alumkal, J.J., Drake, C.G., Thomas, G.V., Redmond, W.L., Farhad, M., Cetnar, J.P., Ey, F.S., Bergan, R.C., Slottke, R., Beer, T.M., 2016a. Early evidence of anti-PD-1 activity in enzalutamide-resistant prostate cancer. Oncotarget.

Graff, J.N., Alumkal, J.J., Drake, C.G., Thomas, G.V., Redmond, W.L., Farhad, M., Slottke, R., Beer, T.M., 2016b. First evidence of significant clinical activity of PD-1 inhibitors in metastatic, castration resistant prostate cancer (mCRPC). Ann. Oncol. 27 (Supp. 6), 243-265.

Grasso, C.S., Wu, Y.M., Robinson, D.R., Cao, X., Dhanasekaran, S.M., Khan, A.P., Quist M.J., Jing, X., Lonigro, R.J., Brenner, J.C., Asangani, I.A., Ateeq, B., Chun, S.Y., Siddiqui, J., Sam, L., Anstett, M., Mehra, R., Prensner, J.R., Palanisamy, N., Ryslik, G.A., Vandin, F., Raphael, B.J., Kunju, L.P., Rhodes, D.R., Pienta, K.J., Chinnaiyan, A.M., Tomlins, S.A., 2012. The mutational landscape of lethal castration-resistant prostate cancer. Nature 487 (7406), 239-243.

Gross, M.E., Dorff, T.B., Quinn, D.I., Massopust, K., Diaz, P.M., Castellanos, O.O., Agus, D.B., 2015. Safety and efficacy of everolimus (E), bevacizumab (B), and docetaxel (D) for castration resistant prostate cancer (CRPC). J. Clin. Oncol. 33 (Suppl) abstr. 5066.

Han, R., Pacifici, M., Iwamoto, M., Trojanowska, M., 2015. Endothelial Erg expression is required for embryogenesis and vascular integrity. Organogenesis 11 (2), 75-86.

Hansen, A., Massard, C., Ott, P.A., Haas, N., Lopez, J., Ejadi, S., Wallmark, J., Keam, B., Delord, J., Aggarwal, R., Gould, M., Qiu, P., 2016. Pembrolizumab for patients with advanced prostate adenocarcinoma: preliminary results from the KEYNOTE-028 study. Ann. Oncol. 27 (6), 243-265.

Harris, K.A., Harney, E., Small, E.J., 2002. Liposomal doxorubicin for the treatment of hormone-refractory prostate cancer. Clin. Prostate Cancer 1 (1), 37-41.

Hirsch, E., Ciraolo, E., Franco, I., Ghigo, A., Martini, M., 2014. PI3K in cancer-stroma interactions: bad in seed and ugly in soil. Oncogene 33 (24), 3083-3090.

Hortobagyi, G.N., Stemmer, S.M., Burris, H.A., Yap, Y.S., Sonke, G.S., Paluch-Shimon, S., Campone, M., Blackwell, K.L., Andre, F., Winer, E.P., Janni, W., Verma, S., Conte, P., Arteaga, C.L., Cameron, D.A., Petrakova, K., Hart, L.L., Villanueva, C., Chan, A., Jakobsen, E., Nusch, A., Burdaeva, O., Grischke, E.M., Alba, E., Wist, E., Marschner, N., Favret, A.M., Yardley, D., Bachelot, T., Tseng, L.M., Blau, S., Xuan, F., Souami, F., Miller, M., Germa, C., Hirawat, S., O'Shaughnessy, J., 2016. Ribociclib as first-line therapy for HR-positive, advanced breast cancer. N. Engl. J. Med. 375 (18), 1738-1748.

Hussain, M., Carducci, M.A., Slovin, S., Cetnar, J., Qian, J., McKeegan, E.M., Refici-Buhr, M., Chyla, B., Shepherd, S.P., Giranda, V.L., Alumkal, J.J., 2014. Targeting DNA repair with combination veliparib (ABT-888) and temozolomide in patients with metastatic castration-resistant prostate cancer. Investig. New Drugs 32 (5), 904-912.

Hussain, M., Daignault, S., Twardowski, P., Albany, C., Stein, M.N., Kunju, L.P., Siddiqui, J., Robinson, D., Mehra, R., 2016. Co-targeting androgen receptor (AR) and DNA repair: a randomized ETS gene fusion-stratified trial of abiraterone + prednisone (Abi) \pm the PARP1 inhibitor veliparib for metastatic castration-resistant prostate cancer (mCRPC) patients (pts) (NCI9012) - A University of Chicago phase II consortium trial. J. Clin. Oncol. 34 (Suppl) abstr. 5010.

Ibuki, N., Ghaffari, M., Pandey, M., Iu, I., Fazli, L., Kashiwagi, M., Tojo, H., Nakanishi, O., Gleave, M.E., Cox, M.E., 2013. TAK-441, a novel investigational smoothened antagonist, delays castration-resistant progression in prostate cancer by disrupting paracrine hedgehog signaling. Int. J. Cancer 133 (8), 1955-1966.

Iljin, K., Wolf, M., Edgren, H., Gupta, S., Kilpinen, S., Skotheim, R.I., Peltola, M., Smit, F., Verhaegh, G., Schalken, J., Nees, M., Kallioniemi, O., 2006. TMPRSS2 fusions with oncogenic ETS factors in prostate cancer involve unbalanced genomic rearrangements and are associated with HDAC1 and epigenetic reprogramming. Cancer Res. 66 (21), 10242-10246.

Jasinski, M., Jasinska, L., Ogrodowczyk, M., 2013. Resveratrol in prostate diseases - a short review. Central Eur. J. Urol. 66 (2), 144-149.

Jemal, A., Bray, F., Center, M.M., Ferlay, J., Ward, E., Forman, D., 2011. Global cancer statistics. CA: Cancer J. Clin. 61 (2), 69-90.

Jin, Y.R., Yoon, J.K., 2012. The R-spondin family of proteins: emerging regulators of WNT signaling. Int. J. Biochem. Cell Biol. 44 (12), 2278-2287.

Kahn, M., 2014. Can we safely target the WNT pathway? Nat. Rev. Drug Discov. 13 (7), 513-532.

Kalderon, D., 2002. Similarities between the Hedgehog and Wnt signaling pathways. Trends Cell Biol. 12 (11), 523-531.

Kantoff, P.W., Higano, C.S., Shore, N.D., Berger, E.R., Small, E.J., Penson, D.F., Redfern, C.H., Ferrari, A.C., Dreicer, R., Sims, R.B., Xu, Y., Frohlich, M.W., Schellhammer, P.F., 2010. Sipuleucel-T immunotherapy for castration-resistant prostate cancer. N. Engl. J. Med. 363 (5), 411-422.

Kareta, M.S., Gorges, L.L., Hafeez, S., Benayoun, B.A., Marro, S., Zmoos, A.F., Cecchini, M.J., Spacek, D., Batista, L.F., O'Brien, M., Ng, Y.H., Ang, C.E., Vaka, D., Artandi, S.E., Dick, F.A., Brunet, A., Sage, J., Wernig, M., 2015. Inhibition of pluripotency networks by the Rb tumor suppressor restricts reprogramming and tumorigenesis. Cell Stem Cell 16 (1), 39-50.

Karhadkar, S.S., Bova, G.S., Abdallah, N., Dhara, S., Gardner, D., Maitra, A., Isaacs, J.T., Berman, D.M., Beachy, P.A., 2004. Hedgehog signalling in prostate regeneration, neoplasia and metastasis. Nature 431 (7009), 707-712.

Karlou, M., Lu, J.F., Wu, G., Maity, S., Tzelepi, V., Navone, N.M., Hoang, A., Logothetis, C.J., Efstathiou, E., 2012. Hedgehog signaling inhibition by the small molecule smoothened inhibitor GDC-0449 in the bone forming prostate cancer xenograft MDA
PCa 118b. Prostate 72 (15), 1638-1647.

Karzai, F., Madan, R.A., Owens, H., Hankin, A., Couvillon, A., Houston, N.D., Fakhrejahani, F., Bilusic, M., Theoret, M.R., 2017. A phase II study of the anti-programmed death ligand-1 antibody durvalumab (D; MEDI4736) in combination with PARP inhibitor, olaparib (O), in metastatic castration-resistant prostate cancer (mCRPC). J. Clin. Oncol. 35 (Suppl. 6S) abstr. 162.

Kattan, J., Bachour, M., Farhat, F., El Rassy, E., Assi, T., Ghosn, M., 2016. Phase II trial of weekly Docetaxel, Zoledronic acid, and Celecoxib for castration-resistant prostate cancer. Investig. New Drugs 34 (4), 474-480.

Klein, C.E., Tangen, C.M., Braun, T.J., Hussain, M.H., Peereboom, D.M., Nichols, C.R. Rivkin, S.E., Dakhil, S.R., Crawford, E.D., 2002. SWOG-9510: evaluation of topotecan in hormone refractory prostate cancer: a Southwest Oncology Group study. Prostate 52 (4), 264-268.

Knudsen, E.S., Wang, J.Y., 2010. Targeting the RB-pathway in cancer therapy. Clin. Cancer Res. 16 (4), 1094-1099.

Kolinsky, M.P., Rescigno, P., Bianchini, D., Zafeiriou, Z., Mehra, N., Mateo, J., Riisnaes, R., Crespo, M., Figueiredo, I., 2017. A phase I dose-escalation study of enzalutamide in combination with the AKT inhibitor AZD5363 in patients with mCRPC. J. Clin. Oncol. 35 (Suppl. 6S) abstr. 135.

Kruczek, K., Ratterman, M., Tolzien, K., Sulo, S., Lestingi, T.M., Nabhan, C., 2013. A phase II study evaluating the toxicity and efficacy of single-agent temsirolimus in chemotherapy-naive castration-resistant prostate cancer. Br. J. Cancer 109 (7), 1711-1716.

Kumar, A., Coleman, I., Morrissey, C., Zhang, X., True, L.D., Gulati, R., Etzioni, R., Bolouri, H., Montgomery, B., White, T., Lucas, J.M., Brown, L.G., Dumpit, R.F., DeSarkar, N., Higano, C., Yu, E.Y., Coleman, R., Schultz, N., Fang, M., Lange, P.H., Shendure, J., Vessella, R.L., Nelson, P.S., 2016. Substantial interindividual and limited intraindividual genomic diversity among tumors from men with metastatic prostate cancer. Nat. Med. 22 (4), 369-378.

Kwon, E.D., Drake, C.G., Scher, H.I., Fizazi, K., Bossi, A., van den Eertwegh, A.J., Krainer, M., Houede, N., Santos, R., Mahammedi, H., Ng, S., Maio, M., Franke, F.A., Sundar, S., Agarwal, N., Bergman, A.M., Ciuleanu, T.E., Korbenfeld, E., Sengelov, L., Hansen, S., Logothetis, C., Beer, T.M., McHenry, M.B., Gagnier, P., Liu, D., Gerritsen, W.R., 2014. Ipilimumab versus placebo after radiotherapy in patients with metastatic castration-resistant prostate cancer that had progressed after docetaxel chemotherapy (CA184-043): a multicentre, randomised, double-blind, phase 3 trial. Lancet Oncol. 15 (7), 700-712.

Lai, S.L., Chien, A.J., Moon, R.T., 2009. Wnt/Fz signaling and the cytoskeleton: potential roles in tumorigenesis. Cell Res. 19 (5), 532-545.

Lauth, M., Bergstrom, A., Shimokawa, T., Toftgard, R., 2007. Inhibition of GLI-mediated transcription and tumor cell growth by small-molecule antagonists. Proc. Natl. Acad. Sci. U. S. A. 104 (20), 8455-8460.

Le, D.T., Uram, J.N., Wang, H., Bartlett, B.R., Kemberling, H., Eyring, A.D., Skora, A.D., Luber, B.S., Azad, N.S., Laheru, D., Biedrzycki, B., Donehower, R.C., Zaheer, A., Fisher, G.A., Crocenzi, T.S., Lee, J.J., Duffy, S.M., Goldberg, R.M., de la Chapelle, A., Koshiji, M., Bhaijee, F., Huebner, T., Hruban, R.H., Wood, L.D., Cuka, N., Pardoll, D.M., Papadopoulos, N., Kinzler, K.W., Zhou, S., Cornish, T.C., Taube, J.M., Anders, R.A., Eshleman, J.R., Vogelstein, B., Diaz Jr., L.A., 2015. PD-1 blockade in tumors with mismatch-repair deficiency. N. Engl. J. Med. 372 (26), 2509-2520.

Lee, S.H., Johnson, D., Luong, R., Sun, Z., 2015. Crosstalking between androgen and PI3K/AKT signaling pathways in prostate cancer cells. J. Biol. Chem. 290 (5), 2759-2768.

Li, X., Placencio, V., Iturregui, J.M., Uwamariya, C., Sharif-Afshar, A.R., Koyama, T. Hayward, S.W., Bhowmick, N.A., 2008. Prostate tumor progression is mediated by a paracrine TGF-beta/Wnt3a signaling axis. Oncogene 27 (56), 7118-7130.

Lin, J.J., Shaw, A.T., 2016. Resisting resistance: targeted therapies in lung cancer. Trends Cancer 2 (7), 350-364.

Liu, X., Chen, X., Rycaj, K., Chao, H.P., Deng, Q., Jeter, C., Liu, C., Honorio, S., Li, H., Davis, T., Suraneni, M., Laffin, B., Qin, J., Li, Q., Yang, T., Whitney, P., Shen, J., Huang, J., Tang, D.G., 2015. Systematic dissection of phenotypic, functional, and tumorigenic heterogeneity of human prostate cancer cells. Oncotarget 6 (27), 23959-23986.

Long, R.M., Morrissey, C., Fitzpatrick, J.M., Watson, R.W., 2005. Prostate epithelial cell differentiation and its relevance to the understanding of prostate cancer therapies. Clin. Sci. (Lond.) 108 (1), 1-11.

Lorente, D., De Bono, J.S., 2014. Molecular alterations and emerging targets in castration resistant prostate cancer. Eur. J. Cancer (Oxf., Engl.: 1990) 50 (4), 753-764.

Lotan, T.L., Wei, W., Morais, C.L., Hawley, S.T., Fazli, L., Hurtado-Coll, A., Troyer, D. McKenney, J.K., Simko, J., Carroll, P.R., Gleave, M., Lance, R., Lin, D.W., Nelson, P.S., Thompson, I.M., True, L.D., Feng, Z., Brooks, J.D., 2016. PTEN loss as determined by clinical-grade immunohistochemistry assay is associated with worse recurrence-free survival in prostate cancer. Eur. Urol. Focus 2 (2), 180-188.

Lu, W., Liu, C.C., Thottassery, J.V., Bu, G., Li, Y., 2010. Mesd is a universal inhibitor of Wnt coreceptors LRP5 and LRP6 and blocks Wnt/beta-catenin signaling in cancer cells. Biochemistry 49 (22), 4635-4643.

Lu, W., Tinsley, H.N., Keeton, A., Qu, Z., Piazza, G.A., Li, Y., 2009. Suppression of Wnt/ beta-catenin signaling inhibits prostate cancer cell proliferation. Eur. J. Pharmacol. $602(1), 8-14$

Luo, J., Manning, B.D., Cantley, L.C., 2003. Targeting the PI3K-Akt pathway in human cancer: rationale and promise. Cancer Cell 4 (4), 257-262.

Leuprolide Acetate or Goserelin Acetate With or Without Vismodegib Followed by Surgery in Treating Patients With Locally Advanced Prostate Cancer. NCT01163084. ClinicalTrials.gov.

Mahal, B.A., Aizer, A.A., Efstathiou, J.A., Nguyen, P.L., 2016. Association of very low prostate-specific antigen levels with increased cancer-specific death in men with high-grade prostate cancer. Cancer 122 (1), 78-83.

Marhold, M., Tomasich, E., El-Gazzar, A., Heller, G., Spittler, A., Horvat, R., Krainer, M. Horak, P., 2015. HIF1alpha regulates mTOR signaling and viability of prostate cancer stem cells. Mol. Cancer Res.: MCR 13 (3), 556-564.

Masoud, G.N., Li, W., 2015. HIF-1alpha pathway: role, regulation and intervention for cancer therapy. Acta Pharmaceut. Sin. B 5 (5), 378-389. 
Mateo, J., Carreira, S., Sandhu, S., Miranda, S., Mossop, H., Perez-Lopez, R., Nava Rodrigues, D., Robinson, D., Omlin, A., Tunariu, N., Boysen, G., Porta, N., Flohr, P., Gillman, A., Figueiredo, I., Paulding, C., Seed, G., Jain, S., Ralph, C., Protheroe, A., Hussain, S., Jones, R., Elliott, T., McGovern, U., Bianchini, D., Goodall, J., Zafeiriou, Z., Williamson, C.T., Ferraldeschi, R., Riisnaes, R., Ebbs, B., Fowler, G., Roda, D., Yuan, W., Wu, Y.M., Cao, X., Brough, R., Pemberton, H., A'Hern, R., Swain, A., Kunju, L.P., Eeles, R., Attard, G., Lord, C.J., Ashworth, A., Rubin, M.A., Knudsen, K.E., Feng, F.Y., Chinnaiyan, A.M., Hall, E., de Bono, J.S., 2015. DNA-repair defects and olaparib in metastatic prostate cancer. N. Engl. J. Med. 373 (18), 1697-1708.

McNeel, D.G., Bander, N.H., Beer, T.M., Drake, C.G., Fong, L., Harrelson, S., Kantoff, P.W., Madan, R.A., Oh, W.K., Peace, D.J., Petrylak, D.P., Porterfield, H., Sartor, O., Shore, N.D., Slovin, S.F., Stein, M.N., Vieweg, J., Gulley, J.L., 2016. The Society for Immunotherapy of Cancer consensus statement on immunotherapy for the treatment of prostate carcinoma. J. Immunother. Cancer 4, 92.

Messina, C., Buzzatti, G., Dellepiane, C., Cavo, A., Tolomeo, F., Cattrini, C., Boccardo, F., 2016. Genitourinary tumours in the targeted therapies era: new advances in clinical practice and future perspectives. Anti-Cancer Drugs 27 (10), 917-943.

Meulenbeld, H.J., de Bono, J.S., Tagawa, S.T., Whang, Y.E., Li, X., Heath, K.H., Zandvliet, A.S., Ebbinghaus, S.W., Hudes, G.R., de Wit, R., 2013. Tolerability, safety and pharmacokinetics of ridaforolimus in combination with bicalutamide in patients with asymptomatic, metastatic castration-resistant prostate cancer (CRPC). Cancer Chemother. Pharmacol. 72 (4), 909-916.

Meyer, A., Cygan, P., Tolzien, K., Galvez, A.G., Bitran, J.D., Lestingi, T.M., Nabhan, C., 2014. Role of sorafenib in overcoming resistance of chemotherapy-failure castrationresistant prostate cancer. Clin. Genitourin Cancer 12 (2), 100-105.

Minet, E., Mottet, D., Michel, G., Roland, I., Raes, M., Remacle, J., Michiels, C., 1999. Hypoxia-induced activation of HIF-1: role of HIF-1alpha-Hsp90 interaction. FEBS Lett. 460 (2), 251-256.

Miyamoto, D.T., Zheng, Y., Wittner, B.S., Lee, R.J., Zhu, H., Broderick, K.T., Desai, R., Fox, D.B., Brannigan, B.W., Trautwein, J., Arora, K.S., Desai, N., Dahl, D.M., Sequist, L.V., Smith, M.R., Kapur, R., Wu, C.L., Shioda, T., Ramaswamy, S., Ting, D.T., Toner, M., Maheswaran, S., Haber, D.A., 2015. RNA-Seq of single prostate CTCs implicates noncanonical Wnt signaling in antiandrogen resistance. Science 349 (6254), 1351-1356.

Mosquera, J.M., Beltran, H., Park, K., MacDonald, T.Y., Robinson, B.D., Tagawa, S.T., Perner, S., Bismar, T.A., Erbersdobler, A., Dhir, R., Nelson, J.B., Nanus, D.M., Rubin, M.A., 2013. Concurrent AURKA and MYCN gene amplifications are harbingers of lethal treatment-related neuroendocrine prostate cancer. Neoplasia (New York, N.Y.) 15 (1), 1-10.

Na, R., Zheng, S.L., Hand, M., Yub, H.D., Shah, J., Ewing, S., Zhang, C.M., Novakovic, L., Petkewicz, K.J., 2016. Germline Mutations in ATM and BRCA1/2 distinguish risk for lethal and indolent prostate cancer and are associated with early age at death. Eur. Urol.

Nabhan, C., Villines, D., Valdez, T.V., Tolzien, K., Lestingi, T.M., Bitran, J.D., Christner, S.M., Egorin, M.J., Beumer, J.H., 2012. Phase I study investigating the safety and feasibility of combining imatinib mesylate (Gleevec) with sorafenib in patients with refractory castration-resistant prostate cancer. Br. J. Cancer 107 (4), 592-597.

Nakabayashi, M., Werner, L., Courtney, K.D., Buckle, G., Oh, W.K., Bubley, G.J., Hayes, J.H., Weckstein, D., Elfiky, A., Sims, D.M., Kantoff, P.W., Taplin, M.E., 2012. Phase II trial of RAD001 and bicalutamide for castration-resistant prostate cancer. BJU Int. 110 (11), 1729-1735.

NCCN Guidelines Prostate Cancer. National Comprehensive Cancer Network v1.17.

NCIC, C.T.G., 2013. NCIC CTG, IND-205: a phase II study of PX-866 in patients with recurrent or metastatic castration-resistant prostate cancer (CRPC). J. Clin. Oncol. 31 (Suppl) abstr. 5042.

Network, C.G.A.R., 2015. The molecular taxonomy of primary prostate cancer. Cell 163 (4), 1011-1025.

Nguyen, D.P., Li, J., Tewari, A.K., 2014. Inflammation and prostate cancer: the role of interleukin 6 (IL-6). BJU Int. 113 (6), 986-992.

Nguyen, L.T., Tretiakova, M.S., Silvis, M.R., Lucas, J., Klezovitch, O., Coleman, I., Bolouri, H., Kutyavin, V.I., Morrissey, C., True, L.D., Nelson, P.S., Vasioukhin, V., 2015. ERG activates the YAP1 transcriptional program and induces the development of age-related prostate tumors. Cancer Cell 27 (6), 797-808.

Nuzzo, P.V., Buzzatti, G., Ricci, F., Rubagotti, A., Argellati, F., Zinoli, L., Boccardo, F. 2014. Periostin: a novel prognostic and therapeutic target for genitourinary cancer? Clin. Genitourin Cancer 12 (5), 301-311.

O'Connor, M.J., Martin, N.M., Smith, G.C., 2007. Targeted cancer therapies based on the inhibition of DNA strand break repair. Oncogene 26 (56), 7816-7824.

Ordonez, J.L., Amaral, A.T., Carcaboso, A.M., Herrero-Martin, D., del Carmen GarciaMacias, M., Sevillano, V., Alonso, D., Pascual-Pasto, G., San-Segundo, L., Vila-Ubach, M., Rodrigues, T., Fraile, S., Teodosio, C., Mayo-Iscar, A., Aracil, M., Galmarini, C.M., Tirado, O.M., Mora, J., de Alava, E., 2015. The PARP inhibitor olaparib enhances the sensitivity of Ewing sarcoma to trabectedin. Oncotarget 6 (22), 18875-18890.

Packer, J.R., Maitland, N.J., 2016. The molecular and cellular origin of human prostate cancer. Biochim. Biophys. Acta 1863 (6 (Pt A)), 1238-1260.

Palanisamy, N., Ateeq, B., Kalyana-Sundaram, S., Pflueger, D., Ramnarayanan, K., Shankar, S., Han, B., Cao, Q., Cao, X., Suleman, K., Kumar-Sinha, C., Dhanasekaran, S.M., Chen, Y.B., Esgueva, R., Banerjee, S., LaFargue, C.J., Siddiqui, J., Demichelis, F., Moeller, P., Bismar, T.A., Kuefer, R., Fullen, D.R., Johnson, T.M., Greenson, J.K., Giordano, T.J., Tan, P., Tomlins, S.A., Varambally, S., Rubin, M.A., Maher, C.A., Chinnaiyan, A.M., 2010. Rearrangements of the RAF kinase pathway in prostate cancer, gastric cancer and melanoma. Nat. Med. 16 (7), 793-798.

Palmgren, J.S., Karavadia, S.S., Wakefield, M.R., 2007. Unusual and underappreciated: small cell carcinoma of the prostate. Semin. Oncol. 34 (1), 22-29.

Park, H., Kim, Y., Sul, J.W., Jeong, I.G., Yi, H.J., Ahn, J.B., Kang, J.S., Yun, J., Hwang, J.J., Kim, C.S., 2015. Synergistic anticancer efficacy of MEK inhibition and dua PI3K/mTOR inhibition in castration-resistant prostate cancer. Prostate 75 (15), 1747-1759.

Park, J.H., Kwon, H.Y., Sohn, E.J., Kim, K.A., Kim, B., Jeong, S.J., Song, J.H., Koo, J.S., Kim, S.H., 2013. Inhibition of Wnt/beta-catenin signaling mediates ursolic acid-induced apoptosis in PC-3 prostate cancer cells. Pharmacol. Rep.: PR 65 (5),
1366-1374.

Piccolo, S., Dupont, S., Cordenonsi, M., 2014. The biology of YAP/TAZ: hippo signaling and beyond. Physiol. Rev. 94 (4), 1287-1312.

Pickup, M., Novitskiy, S., Moses, H.L., 2013. The roles of TGFbeta in the tumour microenvironment. Nat. Rev. Cancer 13 (11), 788-799.

Placencio, V.R., Sharif-Afshar, A.R., Li, X., Huang, H., Uwamariya, C., Neilson, E.G., Shen, M.M., Matusik, R.J., Hayward, S.W., Bhowmick, N.A., 2008. Stromal transforming growth factor-beta signaling mediates prostatic response to androgen ablation by paracrine Wnt activity. Cancer Res. 68 (12), 4709-4718.

Pritchard, C.C., Mateo, J., Walsh, M.F., De Sarkar, N., Abida, W., Beltran, H., Garofalo, A., Gulati, R., Carreira, S., Eeles, R., Elemento, O., Rubin, M.A., Robinson, D., Lonigro, R., Hussain, M., Chinnaiyan, A., Vinson, J., Filipenko, J., Garraway, L., Taplin, M.E., AlDubayan, S., Han, G.C., Beightol, M., Morrissey, C., Nghiem, B., Cheng, H.H., Montgomery, B., Walsh, T., Casadei, S., Berger, M., Zhang, L., Zehir, A., Vijai, J., Scher, H.I., Sawyers, C., Schultz, N., Kantoff, P.W., Solit, D., Robson, M., Van Allen, E.M., Offit, K., de Bono, J., Nelson, P.S., 2016. Inherited DNA-repair gene mutations in men with metastatic prostate cancer. N. Engl. J. Med. 375 (5), 443-453.

Phase III Study of DCVAC Added to Standard Chemotherapy for Men With Metastatic Castration Resistant Prostate Cancer (VIABLE). NCT02111577. ClinicalTrials.gov.

Qin, J., Liu, X., Laffin, B., Chen, X., Choy, G., Jeter, C.R., Calhoun-Davis, T., Li, H., Palapattu, G.S., Pang, S., Lin, K., Huang, J., Ivanov, I., Li, W., Suraneni, M.V., Tang, D.G., 2012. The PSA(-/lo) prostate cancer cell population harbors self-renewing longterm tumor-propagating cells that resist castration. Cell Stem Cell 10 (5), 556-569.

Rajan, A., Carter, C.A., Kelly, R.J., Gutierrez, M., Kummar, S., Szabo, E., Yancey, M.A., Ji, J., Mannargudi, B., Woo, S., Spencer, S., Figg, W.D., Giaccone, G., 2012. A phase I combination study of olaparib with cisplatin and gemcitabine in adults with solid tumors. Clin. Cancer Res. 18 (8), 2344-2351.

Rath, N., Olson, M.F., 2012. Rho-associated kinases in tumorigenesis: re-considering ROCK inhibition for cancer therapy. EMBO Rep. 13 (10), 900-908.

Rathkopf, D.E., Larson, S.M., Anand, A., Morris, M.J., Slovin, S.F., Shaffer, D.R., Heller, G., Carver, B., Rosen, N., Scher, H.I., 2015. Everolimus combined with gefitinib in patients with metastatic castration-resistant prostate cancer: Phase $1 / 2$ results and signaling pathway implications. Cancer 121 (21), 3853-3861.

Rathkopf, D.E., Slovin, S.F., Autio, K.A., Delacruz, A., Shelkey, G., Pisano, K., Hullings, M., DeNunzio, M., Morris, M.J., Scher, H.I., 2016. A Phase II study of the dual mTOR Inhibitor MLN0128 in patients with metastatic castration-resistant prostate cancer (mCRPC). J. Clin. Oncol. 34 (Suppl) abstr. e16529.

Reig, O., Marin-Aguilera, M., Carrera, G., Jimenez, N., Pare, L., Garcia-Recio, S., Gaba, L., Pereira, M.V., Fernandez, P., Prat, A., Mellado, B., 2016. TMPRSS2-ERG in blood and docetaxel resistance in metastatic castration-resistant prostate cancer. Eur. Urol. 70 (5), 709-713.

Ribas, A., 2015. Adaptive immune resistance: how cancer protects from immune attack. Cancer Discov. 5 (9), 915-919.

Robinson, D., Van Allen, E.M., Wu, Y.M., Schultz, N., Lonigro, R.J., Mosquera, J.M., Montgomery, B., Taplin, M.E., Pritchard, C.C., Attard, G., Beltran, H., Abida, W., Bradley, R.K., Vinson, J., Cao, X., Vats, P., Kunju, L.P., Hussain, M., Feng, F.Y., Tomlins, S.A., Cooney, K.A., Smith, D.C., Brennan, C., Siddiqui, J., Mehra, R., Chen, Y., Rathkopf, D.E., Morris, M.J., Solomon, S.B., Durack, J.C., Reuter, V.E., Gopalan, A., Gao, J., Loda, M., Lis, R.T., Bowden, M., Balk, S.P., Gaviola, G., Sougnez, C., Gupta, M., Yu, E.Y., Mostaghel, E.A., Cheng, H.H., Mulcahy, H., True, L.D., Plymate, S.R., Dvinge, H., Ferraldeschi, R., Flohr, P., Miranda, S., Zafeiriou, Z., Tunariu, N., Mateo, J., Perez-Lopez, R., Demichelis, F., Robinson, B.D., Schiffman, M., Nanus, D.M., Tagawa, S.T., Sigaras, A., Eng, K.W., Elemento, O., Sboner, A., Heath, E.I., Scher, H.I., Pienta, K.J., Kantoff, P., de Bono, J.S., Rubin, M.A., Nelson, P.S., Garraway, L.A., Sawyers, C.L., Chinnaiyan, A.M., 2015. Integrative clinical genomics of advanced prostate cancer. Cell 161 (5), 1215-1228.

Roubaud, G., Liaw, B.C., Oh, W.K., Mulholland, D.J., 2016. Strategies to avoid treatmentinduced lineage crisis in advanced prostate cancer. Nat. Rev. Clin. Oncol,

Roviello, G., Ravelli, A., Barni, S., Petrelli, F., Bottini, A., Fox, S.B., Generali, D., 2016. Is it time for everolimus-based combination in castration-resistant prostate cancer? Fut. Oncol. (Lond., Engl.) 12 (16), 1849-1852.

Ryan, C.J., Smith, M.R., Fizazi, K., Saad, F., Mulders, P.F., Sternberg, C.N., Miller, K., Logothetis, C.J., Shore, N.D., Small, E.J., Carles, J., Flaig, T.W., Taplin, M.E., Higano, C.S., de Souza, P., de Bono, J.S., Griffin, T.W., De Porre, P., Yu, M.K., Park, Y.C., Li, J., Kheoh, T., Naini, V., Molina, A., Rathkopf, D.E., 2015. Abiraterone acetate plus prednisone versus placebo plus prednisone in chemotherapy-naive men with metastatic castration-resistant prostate cancer (COU-AA-302): final overall survival analysis of a randomised, double-blind, placebo-controlled phase 3 study. Lancet Oncol. 16 (2), 152-160.

Ryan, C.W., Stadler, W.M., Vogelzang, N.J., 2005. A phase I/II dose-escalation study of exisulind and docetaxel in patients with hormone-refractory prostate cancer. BJU Int. 95 (7), 963-968

A Randomized, Double-blind, Phase 3 Efficacy Trial of PROSTVAC-V/F + /- GM-CSF in Men With Asymptomatic or Minimally Symptomatic Metastatic Castrate-Resistant Prostate Cancer (Prospect). NCT01322490. ClinicalTrials.gov.

Randomized, Open-label, Neoadjuvant Phase 2 Study Comparing the Effects of AR Inhibition With and Without SRC or MEK Inhibition on the Development of EMT in Prostate Cancer. NCT01990196. ClinicalTrials.gov.

Safarinejad, M.R., 2010. Safety and efficacy of sorafenib in patients with castrate resistant prostate cancer: a Phase II study. Urol. Oncol. 28 (1), 21-27.

Schumacher, T.N., Schreiber, R.D., 2015. Neoantigens in cancer immunotherapy. Science (New York, N.Y.) 348 (6230), 69-74.

Sella, A., Yarom, N., Zisman, A., Kovel, S., 2009. Paclitaxel, estramustine and carboplatin combination chemotherapy after initial docetaxel-based chemotherapy in castrationresistant prostate cancer. Oncology 76 (6), 442-446.

Sfanos, K.S., De Marzo, A.M., 2012. Prostate cancer and inflammation: the evidence. Histopathology 60 (1), 199-215.

Shao, L., Zhou, Z., Cai, Y., Castro, P., Dakhov, O., Shi, P., Bai, Y., Ji, H., Shen, W., Wang, J., 2013. Celastrol suppresses tumor cell growth through targeting an AR-ERG-NFkappaB pathway in TMPRSS2/ERG fusion gene expressing prostate cancer. PLOS ONE 8 (3), e58391. 
Shariat, S.F., Kattan, M.W., Traxel, E., Andrews, B., Zhu, K., Wheeler, T.M., Slawin, K.M., 2004. Association of pre- and postoperative plasma levels of transforming growth factor beta(1) and interleukin 6 and its soluble receptor with prostate cancer progression. Clin. Cancer Res. 10 (6), 1992-1999.

Shariat, S.F., Semjonow, A., Lilja, H., Savage, C., Vickers, A.J., Bjartell, A., 2011. Tumor markers in prostate cancer I: blood-based markers. Acta Oncol. 50 (Suppl. 1), 61-75.

Sharma, G., Sharma, A.R., Seo, E.M., Nam, J.S., 2015. Genetic polymorphism in extracellular regulators of Wnt signaling pathway. Biomed. Res. Int. 2015, 847529.

Sheng, X., Li, W.B., Wang, D.L., Chen, K.H., Cao, J.J., Luo, Z., He, J., Li, M.C., Liu, W.J., $\mathrm{Yu}, \mathrm{C}$, , 2015. YAP is closely correlated with castration-resistant prostate cancer, and downregulation of YAP reduces proliferation and induces apoptosis of PC-3 cells. Mol. Med. Rep. 12 (4), 4867-4876.

Siegel, A.P., Bryce, A.H., Lin, A.M., Friedlander, T.W., Hsieh, A.C., Hang, E., Weinberg, V.K., Ryan, C.J., 2014. Results of a multicenter phase I/II trial of abiraterone acetate plus BEZ235 in metastatic, castration-resistant prostate cancer (mCRPC). J. Clin. Oncol. 32 (Suppl) abstr. e16042.

Siegel, R.L., Miller, K.D., Jemal, A., 2016. Cancer statistics, 2016. CA: Cancer J. Clin. 66 (1), 7-30.

Sinibaldi, V.J., Elza-Brown, K., Schmidt, J., Eisenberger, M.A., Rosenbaum, E., Denmeade, S.R., Pili, R., Walczak, J., Baker, S.D., Zahurak, M., Carducci, M.A., 2006. Phase II evaluation of docetaxel plus exisulind in patients with androgen independent prostate carcinoma. Am. J. Clin. Oncol. 29 (4), 395-398.

Sittadjody, S., Thangasamy, T., NickKolgh, B., Balaji, K.C., 2016. Non-androgen Signaling Pathways in Castration-Resistant Prostate Cancer. Springer International Publishing, Switzerland.

Steinbild, S., Mross, K., Frost, A., Morant, R., Gillessen, S., Dittrich, C., Strumberg, D., Hochhaus, A., Hanauske, A.R., Edler, L., Burkholder, I., Scheulen, M., 2007. A clinical phase II study with sorafenib in patients with progressive hormone-refractory prostate cancer: a study of the CESAR Central European Society for Anticancer Drug Research-EWIV. Br. J. Cancer 97 (11), 1480-1485.

Sternberg, C.N., Petrylak, D.P., Sartor, O., Witjes, J.A., Demkow, T., Ferrero, J.M., Eymard, J.C., Falcon, S., Calabro, F., James, N., Bodrogi, I., Harper, P., Wirth, M. Berry, W., Petrone, M.E., McKearn, T.J., Noursalehi, M., George, M., Rozencweig, M., 2009. Multinational, double-blind, phase III study of prednisone and either satraplatin or placebo in patients with castrate-refractory prostate cancer progressing after prior chemotherapy: the SPARC trial. J. Clin. Oncol. 27 (32), 5431-5438.

Stoyanova, T., Riedinger, M., Lin, S., Faltermeier, C.M., Smith, B.A., Zhang, K.X., Going, C.C., Goldstein, A.S., Lee, J.K., Drake, J.M., Rice, M.A., Hsu, E.C., Nowroozizadeh, B., Castor, B., Orellana, S.Y., Blum, S.M., Cheng, D., Pienta, K.J., Reiter, R.E., Pitteri, S.J., Huang, J., Witte, O.N., 2016. Activation of Notch1 synergizes with multiple pathways in promoting castration-resistant prostate cancer. Proc. Natl. Acad. Sci. U. S. A. 113 (42), E6457-E6466.

Su, Q., Xin, L., 2016. Notch signaling in prostate cancer: refining a therapeutic opportunity. Histol. Histopathol. 31 (2), 149-157.

A Single-Arm, Open-Label, Two-Stage Phase II Study of the MEK 1/2 Inhibitor Trametinib in Men With Progressive Metastatic Castrate Resistant Prostate Cancer. NCT02881242. ClinicalTrials.gov.

Study of Pembrolizumab (MK-3475) in Participants With Metastatic Castration-Resistant Prostate Cancer (mCRPC) Previously Treated With Chemotherapy (MK-3475-199/ KEYNOTE-199). NCT02787005. ClinicalTrials.gov.

Taipale, J., Beachy, P.A., 2001. The Hedgehog and Wnt signalling pathways in cancer. Nature 411 (6835), 349-354.

Tan, H.L., Sood, A., Rahimi, H.A., Wang, W., Gupta, N., Hicks, J., Mosier, S., Gocke, C.D., Epstein, J.I., Netto, G.J., Liu, W., Isaacs, W.B., De Marzo, A.M., Lotan, T.L., 2014. Rb loss is characteristic of prostatic small cell neuroendocrine carcinoma. Clin. Cancer Res. 20 (4), 890-903.

Taylor, B.S., Schultz, N., Hieronymus, H., Gopalan, A., Xiao, Y., Carver, B.S., Arora, V.K., Kaushik, P., Cerami, E., Reva, B., Antipin, Y., Mitsiades, N., Landers, T., Dolgalev, I., Major, J.E., Wilson, M., Socci, N.D., Lash, A.E., Heguy, A., Eastham, J.A., Scher, H.I., Reuter, V.E., Scardino, P.T., Sander, C., Sawyers, C.L., Gerald, W.L., 2010. Integrative genomic profiling of human prostate cancer. Cancer Cell 18 (1), 11-22.

Templeton, A.J., Dutoit, V., Cathomas, R., Rothermundt, C., Bartschi, D., Droge, C., Gautschi, O., Borner, M., Fechter, E., Stenner, F., Winterhalder, R., Muller, B., Schiess, R., Wild, P.J., Ruschoff, J.H., Thalmann, G., Dietrich, P.Y., Aebersold, R., Klingbiel, D., Gillessen, S., 2013. Phase 2 trial of single-agent everolimus in chemotherapy-naive patients with castration-resistant prostate cancer (SAKK 08/08). Eur. Urol. 64 (1), 150-158.

Thakur, M.K., Heilbrun, L.K., Sheng, S., Stein, M., Liu, G., Antonarakis, E.S. Vaishampayan, U., Dzinic, S.H., Li, X., Freeman, S., Smith, D., Heath, E.I., 2016. A phase II trial of ganetespib, a heat shock protein 90 Hsp90) inhibitor, in patients with docetaxel-pretreated metastatic castrate-resistant prostate cancer (CRPC)-a prostate cancer clinical trials consortium (PCCTC) study. Investig. New Drugs 34 (1), $112-118$.
Tomlins, S.A., Rhodes, D.R., Perner, S., Dhanasekaran, S.M., Mehra, R., Sun, X.W., Varambally, S., Cao, X., Tchinda, J., Kuefer, R., Lee, C., Montie, J.E., Shah, R.B., Pienta, K.J., Rubin, M.A., Chinnaiyan, A.M., 2005. Recurrent fusion of TMPRSS2 and ETS transcription factor genes in prostate cancer. Science 310 (5748), 644-648.

Topalian, S.L., Hodi, F.S., Brahmer, J.R., Gettinger, S.N., Smith, D.C., McDermott, D.F., Powderly, J.D., Carvajal, R.D., Sosman, J.A., Atkins, M.B., Leming, P.D., Spigel, D.R., Antonia, S.J., Horn, L., Drake, C.G., Pardoll, D.M., Chen, L., Sharfman, W.H., Anders, R.A., Taube, J.M., McMiller, T.L., Xu, H., Korman, A.J., Jure-Kunkel, M., Agrawal, S., McDonald, D., Kollia, G.D., Gupta, A., Wigginton, J.M., Sznol, M., 2012. Safety, activity, and immune correlates of anti-PD-1 antibody in cancer. N. Engl. J. Med. 366 (26), 2443-2454.

Toren, P., Kim, S., Johnson, F., Zoubeidi, A., 2016. Combined AKT and MEK pathway blockade in pre-clinical models of enzalutamide-resistant prostate cancer. PLOS ONE 11 (4), e0152861.

Turner, N.C., Ro, J., Andre, F., Loi, S., Verma, S., Iwata, H., Harbeck, N., Loibl, S., Huang Bartlett, C., Zhang, K., Giorgetti, C., Randolph, S., Koehler, M., Cristofanilli, M., 2015. Palbociclib in hormone-receptor-positive advanced breast cancer. N. Engl. J. Med. 373 (3), 209-219.

TOPARP: A Phase II Trial of Olaparib in Patients With Advanced Castration Resistant Prostate Cancer (TOPARP) NCT01682772. ClinicalTrials.gov.

Vaishampayan, U., Shevrin, D., Stein, M., Heilbrun, L., Land, S., Stark, K., Li, J., Dickow, B., Heath, E., Smith, D., Fontana, J., 2015. Phase II trial of carboplatin, everolimus, and prednisone in metastatic castration-resistant prostate cancer pretreated with docetaxel chemotherapy: a prostate cancer clinical trial consortium study. Urology 86 (6), 1206-1211.

Virag, L., Szabo, C., 2002. The therapeutic potential of poly(ADP-ribose) polymerase inhibitors. Pharmacol. Rev. 54 (3), 375-429.

Wang, X., Kruithof-de Julio, M., Economides, K.D., Walker, D., Yu, H., Halili, M.V., Hu, Y.P., Price, S.M., Abate-Shen, C., Shen, M.M., 2009. A luminal epithelial stem cell that is a cell of origin for prostate cancer. Nature 461 (7263), 495-500.

Wang, Z.A., Toivanen, R., Bergren, S.K., Chambon, P., Shen, M.M., 2014. Luminal cells are favored as the cell of origin for prostate cancer. Cell Rep. 8 (5), 1339-1346.

Watson, P.A., Arora, V.K., Sawyers, C.L., 2015. Emerging mechanisms of resistance to androgen receptor inhibitors in prostate cancer. Nat. Rev. Cancer 15 (12), 701-711.

Weinberg, R.A., 2014. The Biology of Cancer. 2nd ed. Garland Science, New York.

Wu, H., Zhang, L., Gao, X., Zhang, X., Duan, J., You, L., Cheng, Y., Bian, J., Zhu, Q., Yang, Y., 2017. Combination of sorafenib and enzalutamide as a potential new approach for the treatment of castration-resistant prostate cancer. Cancer Lett. 385, 108-116.

Wu, Y., Chhipa, R.R., Cheng, J., Zhang, H., Mohler, J.L., Ip, C., 2010. Androgen receptormTOR crosstalk is regulated by testosterone availability: implication for prostate cancer cell survival. Anticancer Res. 30 (10), 3895-3901.

Wyatt, A.W., Gleave, M.E., 2015. Targeting the adaptive molecular landscape of castration-resistant prostate cancer. EMBO Mol. Med. 7 (7), 878-894.

Wyatt, A.W., Mo, F., Wang, Y., Collins, C.C., 2013. The diverse heterogeneity of molecular alterations in prostate cancer identified through next-generation sequencing. Asian J. Androl. 15 (3), 301-308.

Wyce, A., Degenhardt, Y., Bai, Y., Le, B., Korenchuk, S., Crouthame, M.C., McHugh, C.F., Vessella, R., Creasy, C.L., Tummino, P.J., Barbash, O., 2013. Inhibition of BET bromodomain proteins as a therapeutic approach in prostate cancer. Oncotarget 4 (12), 2419-2429.

Xue, G., Restuccia, D.F., Lan, Q., Hynx, D., Dirnhofer, S., Hess, D., Ruegg, C., Hemmings, B.A., 2012. Akt/PKB-mediated phosphorylation of Twist1 promotes tumor metastasis via mediating cross-talk between PI3K/Akt and TGF-beta signaling axes. Cancer Discov. 2 (3), 248-259.

Ylitalo, E.B., Thysell, E., Jernberg, E., Lundholm, M., Crnalic, S., Egevad, L., Stattin, P., Widmark, A., Bergh, A., Wikstrom, P., 2016. Subgroups of castration-resistant prostate cancer bone metastases defined through an inverse relationship between androgen receptor activity and immune response. Eur. Urol.

Yuan, X., Wu, H., Xu, H., Xiong, H., Chu, Q., Yu, S., Wu, G.S., Wu, K., 2015. Notch signaling: an emerging therapeutic target for cancer treatment. Cancer Lett. 369 (1), 20-27.

Zanconato, F., Battilana, G., Cordenonsi, M., Piccolo, S., 2016a. YAP/TAZ as therapeutic targets in cancer. Curr. Opin. Pharmacol. 29, 26-33.

Zanconato, F., Cordenonsi, M., Piccolo, S., 2016b. YAP/TAZ at the roots of cancer. Cancer Cell 29 (6), 783-803.

Zhang, L., Yang, S., Chen, X., Stauffer, S., Yu, F., Lele, S.M., Fu, K., Datta, K., Palermo, N., Chen, Y., Dong, J., 2015. The hippo pathway effector YAP regulates motility, invasion, and castration-resistant growth of prostate cancer cells. Mol. Cell Biol. 35 (8), 1350-1362.

Zhao, B., Wei, X., Li, W., Udan, R.S., Yang, Q., Kim, J., Xie, J., Ikenoue, T., Yu, J., Li, L., Zheng, P., Ye, K., Chinnaiyan, A., Halder, G., Lai, Z.C., Guan, K.L., 2007. Inactivation of YAP oncoprotein by the Hippo pathway is involved in cell contact inhibition and tissue growth control. Genes Dev. 21 (21), 2747-2761. 